\title{
BIOCONVERSÃO DE RESÍDUOS DA INDÚSTRIA PESQUEIRA
}

\author{
DORIS FLORIDALMA MORALES ULLOA \\ Nutricionista
}

Orientadora: Prof ${ }^{a} r^{2}$. MARÍLIA OETTERER

Dissertação apresentada à Escola Superior de Agricultura "Luiz de Queiroz", da Universidade de São Paulo, para obtenção do título de Mestre em Ciências, Área de Concentração: Ciência e Tecnologia de Alimentos.

\author{
P IR A C I C A B A \\ Estado de São Paulo - Brasil \\ Setembro - 1994
}


Ficha catalogrefica preparada pela Seça de Livros da

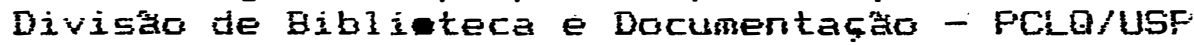

Porales Uliaa, Doris Floridalua

MBzal Eioconversào de resíduos da indústria pesqueira. Firacicaba, 1994.

$112 p$.

Diss. (Mestre) - ESALE

Eibliografia.

1. Industria pesqueira - Fiesidud - Hioconversano

2. Silagen de pescado I. Escola Superior de Agricultul ra Luiz de Queiroz, Firacicaba

CDD 6.36 .09552 


\section{BIOCONVERSÃO DE RESÍDUOS DA INDÚSTRIA PESQUEIRA}

DORIS FLORIDALMA MORALES ULLOA

Aprovada em: 11/11/1994

Comissão julgadora:

Dr. MURILO GRANER - ESALQ/USP

$\mathrm{Dr}^{2}$. SOLANGE G. CANNIATTI BRAZACA - ESALQ/USP

Drª MARÍLIA OETTERER - ESALQ/USP (Orientadora)

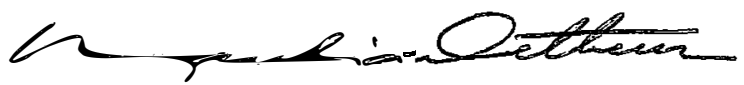

Prof ${ }^{\mathrm{a}}$. Dr ${ }^{\mathrm{a}}$. MARÍLIA OETTERER Orientadora 


\section{A DEUS pelo dom da vida}

\section{Agradeço}

Aos meus pais Ricardo e Elisa, pelo amor e confiança a mim dedicados e pelo exemplo de trabalho, dedicação e honestidade. Aos meus irmãos Leticia e Ricardo, e aos meus sobrinhos Cecilio Alfredo, Renán Alberto, Luis Fernando e Carlos José, pelo carinho, incentivo, cooperação e amor em todas as aspirações e conquistas. Obrigada. 
'A Prof ${ }^{\mathrm{a}}$. Dr ${ }^{\mathrm{a}}$. MARÍLIA OETTERER pela exemplar, honesta, dedicada e brilhante carreira universitária, com carinho. 
- Ao Professor Dr. Jorge Mancini Filho, da FCF-USP pela execução das análises de ácidos graxos.

- À Professora Dra Maria Cristina Stolf Nogueira da ESALQ/USP, pelas análises estatísticas.

- Ao Prof. Dr. Antonio Joaquim de Oliveira e aos Técnicos de Laboratório Cleomar Maria de Carvalho e Carlos Eduardo Garcia pela colaboração prestada.

- Ao colega Valmir Eduardo Alcarde pela doação, assistência e manutenção das culturas utilizadas.

- Aos Técnicos de Laboratório Maria de Lourdes Perin Storer, José Carlos Teixeira Mendes e Carlota B. Prudente dos Anjos da ESALQ/USP, pela colaboração na execução do trabalho.

- Ao Prof. Dr. Marco Antonio Azeredo César pela colaboração prestada.

- Ao especialista em computação Hilkias Arruda Nicolau pela digitação, trabalhos de impressão e sugestões. 
- Aos Professores e Funcionários do Departamento de Ciência e Tecnologia Agroindustrial da ESALQ/USP, pela ajuda, sugestões e cessão de uso de equipamentos.

- Às Bibliotecárias Beatriz Helena Giongo, Mídian Gustinelli, Eliana Maria G. Sabino e Kátia Maria A. Ferraz, pela revisão e busca das referências bibliográficas.

- Aos colegas do Curso de Pós-Graduação pela amizade e estímulos recebidos em especial a Secretária Regina de Mello Lourenço.

- A todas as pessoas que direta ou indiretamente auxiliaram no desenvolvimento deste trabalho.

- Ao povo brasileiro pelo carinho recebido no decorrer de todos esses anos. 


\section{SUMÁRIO}

pág.

RESUMO

$\mathrm{V}$

SUMMARY vii

1. INTRODUÇÃO 01

2. REVISÃO DA LITERATURA 05

2.1. Situação atual da produção e industrialização do pescado 05

2.2. Resíduos de pescado 07

2.2.1. Tipos de resíduos 08

2.2.2. Aproveitamento de resíduos 11

2.3. Silagem de pescado 20

2.3.1. Definições 20

2.3.2. Produção e utilização da silagem 21

2.3.3. Processamento da silagem 25

2.3.4. Estocagem da silagem 28

2.3.5. Valor nutricional 30

2.4. Silagem química de pescado 33

2.4.1. Uso dos ácidos 33

2.4.2. Monitoramento do processamento 36

2.5. Silagem microbiana de pescadó 


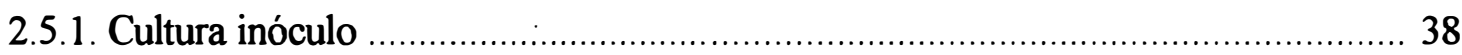

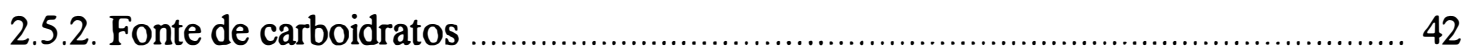

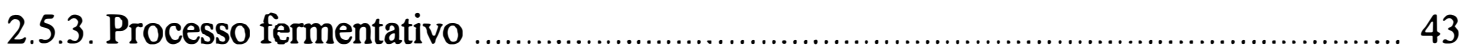

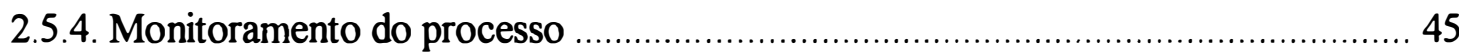

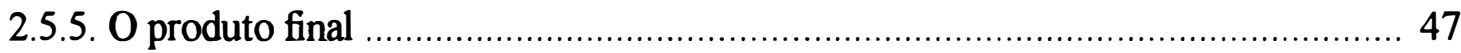

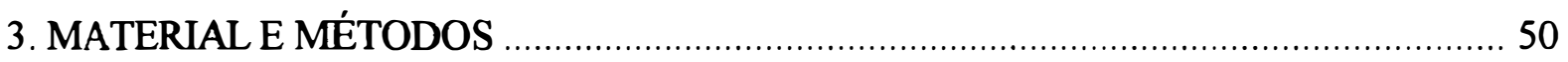

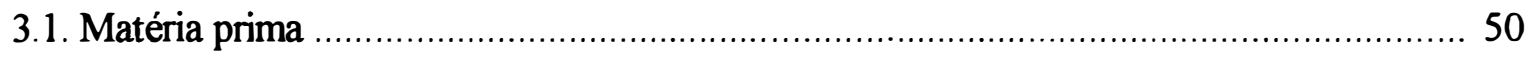

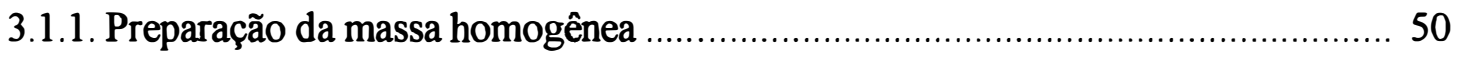

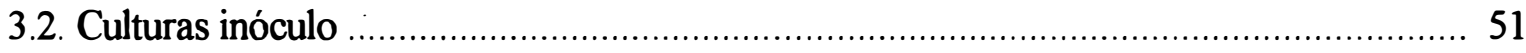

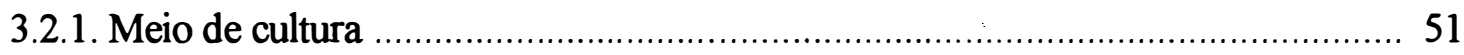

3.2.2. Salução para resuspender as células .......................................................... 52

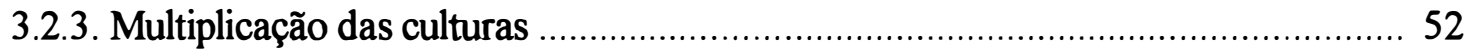

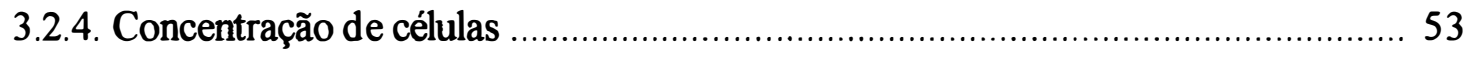

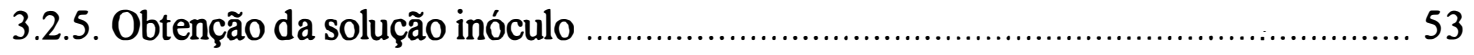

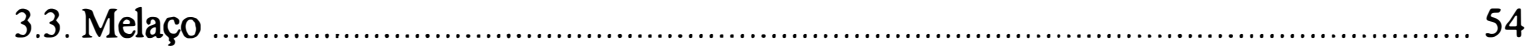

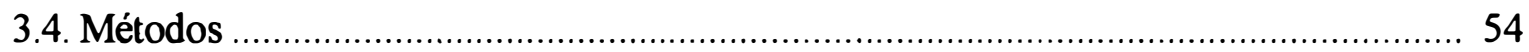

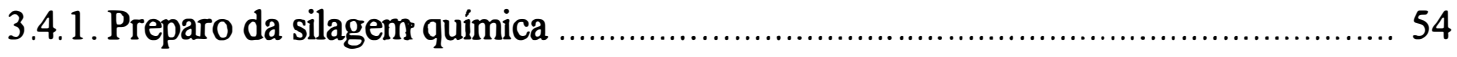

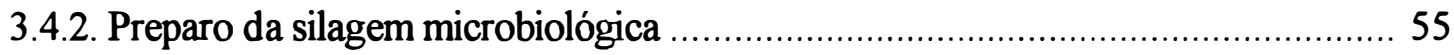

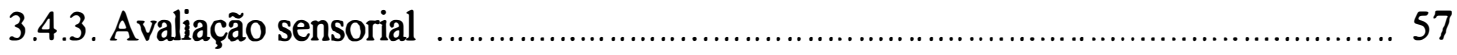

3.4.4. Coleta de amostras das silagens para análise ......................................... 57

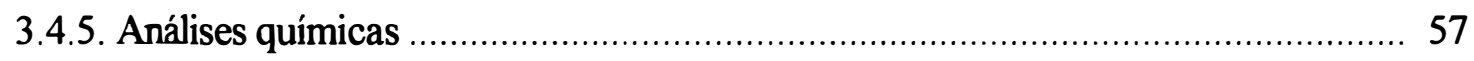

3.4.5.1. Determinação do $\mathrm{pH}$................................................................... 57 
3.4.5.2. Composição centesimal

3.4.5.3. Determinação de Nitrogênio Não Protéico ......................................... 58

3.4.5.4. Determinação de Nitrogênio Protéico .................................................. 59

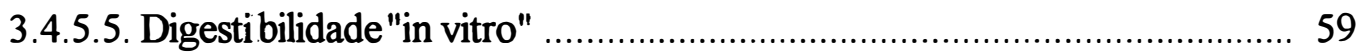

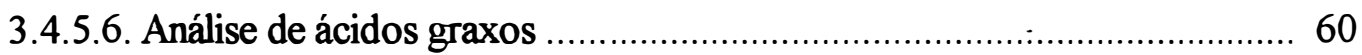

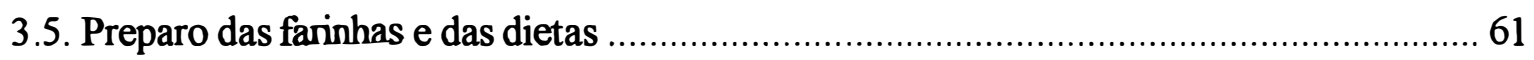

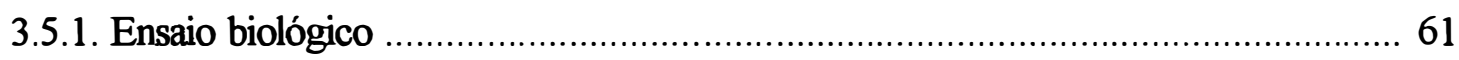

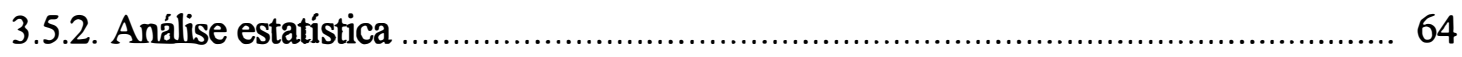

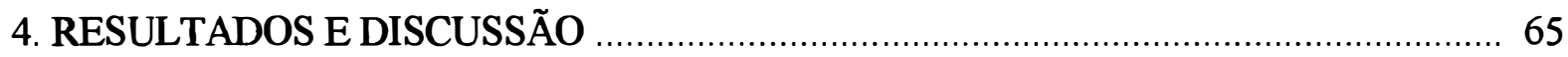

4.1. Fluxograma para produção de silagens microbiológicas de pescado ............................. 65

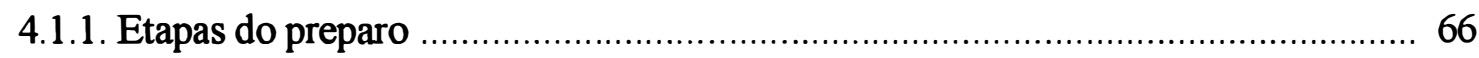

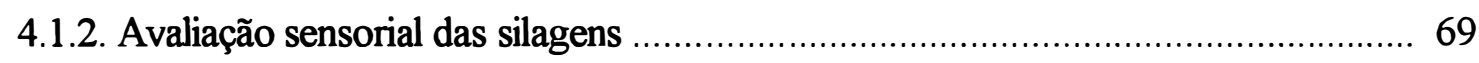

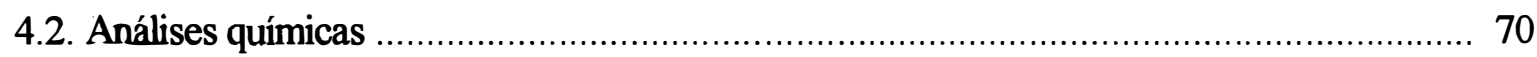

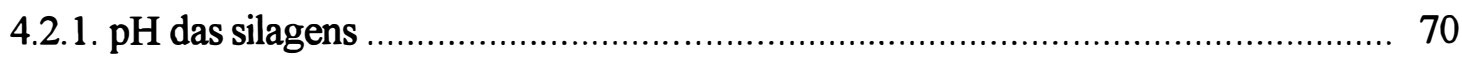

4.2.2. Composição centesimal das silagens .................................................................. 72

4.2.3. Composição em ácidos graxos da fração lipídica das silagens …....................... 79

4.2.4. Fração nitrogenada das silagens ................................................................. 83

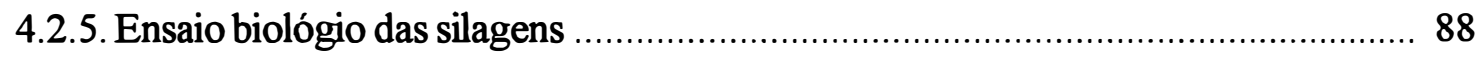

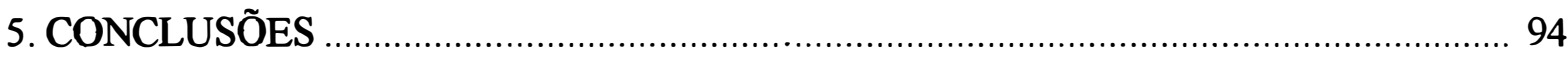

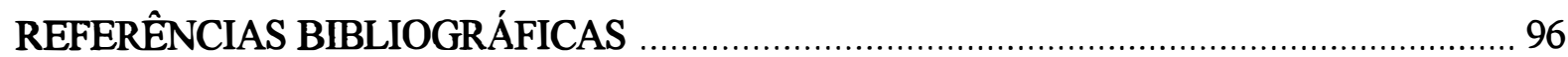




\section{ÍNDICE DE TABELAS}

Pág.

Tabela 1. Composição química das dietas experimentais para o ensaio biológico 62

Tabela 2. $\mathrm{pH}$ da silagem durante as etapas do processo 70

Tahela 3. Teor de umidade e proteína das silagens biológicas nos diferentes tempos de fermentação

Tabela 4. Teor de cinza e de carboidratos das silagens biológicas nos diferentes tempos de fermentação

Tabela 5. Teor de lipídeos das silagens biológicas nos diferentes tempos de fermentação

Tabela 6. Composição em ácidos graxos da fração lipídica das silagens $\operatorname{com} L$. plontarum nos diferentes tempos de fermentação ( $\mathrm{g} / 100 \mathrm{~g}$ lipídios)

Tabela 7. Composição em ácidos graxos da fração lipídica das silagens com $P$. acidilactici nos diferentes tempos de fermentação ( $\mathrm{g} / 100 \mathrm{~g}$ lipídios).

Tabela 8. Teores de nitrogênio total, nitrogênio não protéico e nitrogênio protéico nas silagens biológicas nos diferentes tempos de fementação

Tabela 9. Digestibilidade "in vitro" das silagens biológicas

Tabela 10. Peso inicial, peso final, ganho de peso e consumo de ração dos animais experimentais do ensaio biológico durante 28 dias

Tabela 11. Coeficiente de Eficiência Alimentar (CEA), Razão de Eficiência Protéica (PER), Digestibilidade (D\%), Utilização Proteíca Líquida (NPU) e Valor Biológico (VB), para as dietas experimentais nas diferentes silagens 


\section{RESUMO}

Avaliou-se a possibilidade da utilização dos resíduos da sardinha na produção de silagens microbianas, às quais foram adicionados de melaço como fonte de carboidratos e o $L$. plantarum e o $P$. acidilactici como inóculos. Os resíduos utilizados foram previamente acidificados com uma mistura 1:1 de ácido fórmico e ácido propiônico, na proporção de $3 \%$ v/p. Através da produção de silagens pretende-se contribuir com a indústria na utilização integral da matéria-prima, evitando a descarga desses resíduos, que se constituem em agentes poluentes do meio ambiente.

Para cada microrganismo foram estabelecidas três condições diferentes, a saber: o microrganismo com seu meio de crescimento, o microrganismo com o meio e adição de melaço e o microrganismo centrifugado e suspenso em solução salina e adição de melaço. Durante o experimento foram feitas análises químicas, biológicas e sensoriais, a fim de determinar as modificações ocorridas nas silagens. As silagens foram também avaliadas "in vivo" através de ensaio biológico, no qual foram feitas análises de ganho de peso, CEA (Coeficiente de Eficiência Alimentar), PER (Razão de Eficiência Protéica), NPU (Utilização Protéica Líquida), VB (Valor Biológico) e Digestibilidade (D\%).

As silagens feitas com melaço como fonte de carboidratos, tanto para o L. plantarum como com o $P$. acidilactici, apresentaram coloração marrom escuro, aroma agradável e textura de pasta. 
As diferentes silagens mantiveram-se estáveis, apresentando pH 4,18 - 4,23 após duas semanas de fermentação.

A composição centesimal das silagens com $L$. plantarum e $P$. acidilactici, respectivamente, nas primeiras $48 \mathrm{~h}$, foi a seguinte: umidade $55,94 \%$ e $58,83 \%$; proteína $19,33 \%$ e $17,39 \%$; cinza $3,77 \%$ e $3,32 \%$; carboidratos $18,51 \%$ e 18,15\%; lipídeos $2,45 \%$ e $2,31 \%$.

Após 48 h de fermentação das silagens com $L$. plantarum e $P$. acidilactici houve a conversão do nitrogênio da ordem de $35,18 \%$ e $39,79 \%$. A digestibilidade "in vitro" foi de $84,2 \%$ e $84,5 \%$, mostrando que $48 \mathrm{~h}$ são suficientes para promover a hidrólise da fração protéica. Após 2 semanas de fermentação para as silagens microbianas com $L$. plantanum e $P$. acidilactici a conversão de nitrogênio foi da ordem de $34,22 \%$ e $41,73 \%$ e de digestibilidade de $83,5 \%$ e $81,0 \%$.

A silagem microbiana de pescado preparada a partir de resíduos de sardinha e adição de melaço pode ser usada como alimento, apresentando um CEA de 0,14; PER de 1,47; digestibilidade "in vivo" de $96,31 \%$, NPU de $38,68 \%$ e V.B de $40,19 \%$. 


\section{SUMMARY}

The utilization of canned fishery industry residues to obtain microbian silage production, with addition of molasse as source of carbohydrates and $L$. plantarum and $P$. acidilactici as the culture inoculum was studied. Before the silage preparation the residues were acidificated with mixture 1:1 formic acid and propionic acid in $3 \% \mathrm{v} / \mathrm{w}$.

By the silage production we intended to contribute to the utilization of fishery residues as protein source, usually a problem looking at environmental pollution point of view.

For each microorganism three differential conditions were studied: microorganism and his growth medium, microorganim and his growth medium and molasse, and microoganism centrifuged and hanging in the saline solution and molasse.

In the course of the experiment chemical, biological and sensorial analysis were made, with the purpose of evaluate the changes in the components to convert the residues in silage.

The biological assay for the parameters avaliation as: weight gain, CEA, PER, NPU, VB, digestibility were made.

The silage prepared with molasse as carbohydrates source as much as for the $L$. plantarum and $P$. acidilactici, showed brown color, agreeable and paste 
texture.

The different silage remain stable at the $\mathrm{pH}$ value range from 4.18 to 4.23 after two weeks of fermentation.

The centesimal composition of $L$. plantarum and $P$. acidilactici silage is: moisture $55.94 \%$ and $58.83 \%$; crude protein $19.33 \%$ and $17.39 \%$; ash $3.77 \%$ and $3.32 \%$; carbohydrates $18.51 \%$ and $18.15 \%$; lipids $2.45 \%$ and $2.31 \%$.

After a 48h fermentation to the $L$. plantarum and $P$. acidilactici the Total Nitrogen converted to non Proteic Nitrogen, respectively, was $35.18 \%$ and 38.79\%. The digestibity "in vitro" was $84.2 \%$ and $84.5 \%$, showed that 48 hours are enough to convert the protein fraction.

After two weeks of fermentation for $L$. plantarum and $P$. acidilactici, respectively the nitrogen convertion is $34.22 \%$ and $41.73 \%$ and digestibility "in vitro" is $83.5 \%$ and $81.0 \%$.

The microbian fish silage prepared from the the sardines residues and molasse can be use for food and showed 0.14 CEA; 1.47 PER; 96.31\% digestibility "in vivo"; $38.68 \%$ NPU and $40.19 \%$ BV. 


\section{INTRODUÇÃO}

Os resíduos da industrialização do pescado, representam um sério problema para a indústria por serem poluentes e de difícil descarte, interferindo nos custos e na eficiência de produção.

Nos Estados Unidos, os resíduos sólidos da indústria pesqueira chegam a 6 mil toneladas, das quais 50\% são aproveitadas na elaboração de rações (REBECA et al., 1991).

Na Indonésia estima-se um mínimo de 225 mil toneladas de refugos de peixes que são devolvidos ao mar e cerca de 200.000 toneladas de peixes que não podem ser utilizados devido a deterioração e injúrias; enquanto os resíduos do processamento somam 25.000 toneladas (KOMPIANG, 1981).

O aproveitamento integral dos resíduos da indústria pesqueira, sejam sobras comestíveis das operações de filetagem; das carnes vermelhas provenientes do processamento do atum; das sobras de sardinhas que excedem o tamanho da lata, minimizariam os problemas de poluição ambiental e permitiriam o aparecimento de novos produtos com o que abaixariam os custos de produção. No caso do pescado o material residual se constitui de aparas, carnes escuras, cabeças, carcaças e efluentes em geral. Esses novos produtos seriam destinados ao consumo humano ou ração em 
decorrência da matéria prima utilizada.

A silagem de pescado é um produto líquido preservado pela adição de ácidos ou por fermentação microbiana podendo ser feita a partir do pescado inteiro ou do material residual deste. A liquefação é obtida pela atividade proteolítica das enzimas naturalmente presentes nos peixes (KOMPIANG, 1981).

A silagem é atualmente utilizada para ração animal, porém, não deve ser vista como um competidor da farinha de pescado e sim como uma alternativa na utilização das fontes disponíveis.

O refugo de pescado está disperso por todas as regiões de pesca, as quais não teriam condições de suportar uma planta processadora de farinha; nesses casos a silagem aparece como vantajosa proposta inclusive a nível de pequenas unidades pois, além de utilizar o resíduo, supriria a demanda de farinha de pescado, que às vezes apresenta problemas de custo e importação.

Entre as vantagens de produção de silagem em relação à farinha de pescado temos as seguintes: o processo é virtualmente independente de escala; a tecnologia é simples; o capital necessário é pequeno; mesmo para produção em larga escala, os efluentes e os odores são reduzidos; a silagem pode ser produzida a bordo; não necessita armazenamento refrigerado; o processo é rápido em climas tropicais e o produto pode ser utilizado de imediato. As desvantagens devem ser consideradas: sendo a silagem um produto volumoso, dificulta seu armazenamento e transporte; sendo um produto ácido, causa corrosão nos tanques e o alto teor de gordura de alguns peixes tropicais prejudica o processamento e armazenamento do produto. 
Os resíduos de origem animal representam uma vasta fonte de energia e nutrientes que podem ser reciclados pelo uso de processos de bioconversão. A produção de biomassa permite a produção de produtos de maior digestibilidade. Muitas das sobras atualmente descartadas pela indústria tem um bom mercado, pois representam um rico material alimentício quando recuperado adequadamente (LISTON, 1977; MORAIS \& MARTIN, 1981; TENUTA FILHO, 1983; SEAL, 1992).

SHOEMAKER (1986), afirma que todo resíduo proveniente da industrialização de alimentos será aproveitado no futuro, quer por processos que envolvam os microrganismos e digestão anaeróbica, como a produção atual de "single cell protein", ou empreguem enzimas específicas, como as proteases, para evitar reações indesejáveis que estão associadas ao uso de catalisadores menos específicos.

Em países tropicais, grande quantidade de pescado é perdida, especialmente em pesca de pequeno porte. Pesquisas tem sido conduzidas com o objetivo de utilizar esse recurso e transformá-lo preferencialmente em alimento humano, mas, no entanto, a alternativa tem sido a transformação em ração (DISNEY et al., 1977).

No Brasil, ainda o aproveitamento dos resíduos da comercialização e industrialização do pescado é praticamente nulo; na indústria enlatadora aproveitam-se sobras para preparo de farinha de peixe de baixa qualidade. Estes resíduos são armazenados em tanques sem receber qualquer tratamento, fato que depõe contra a qualidade higiênica dessas plantas. Um manejo adequado desses resíduos, com separação de partes comestíveis e estocagem em condições de acidez elevada possibilitaria à indústria brasileira a preparação de silagem, até mesmo para consumo humano. 
Este trabalho tem como objetivo elaborar e caracterizar química, biológica e sensorialmente silagens microbiológicas preparadas a partir de sardinha.

A bioconversão do material residual, com conseqüente aproveitamento deste, trará vantagens econômicas para a indústria, além de sanar o grande problema de eliminação de resíduos, matéria poluente e portanto, de difícil descarte. 


\section{REVISÃO DE LITERATURA}

\subsection{Situação atual da produção e industrialização do pescado}

Do total da captura mundial de pescado, cerca de $72 \%$ são utilizados nos mercados de pescado fresco, congelado, enlatado e salgado; os $28 \%$ restantes seguem para a produção de ração animal. Os processos de comercialização e industrialização para consumo humano rendem de 25 a $70 \%$ da matéria-prima como produto comestível. Assim, as partes não aproveitáveis somam 20 milhões de toneladas; esta sobra é igual ao peso do pescado inteiro utilizado para fabricação de farinha; o que mostra que mais de 2/3 da captura atual não estão sendo utilizados como alimento humano (LAUBIER, 1979; HOOD \& ZALL, 1979; FAO, 1990; REBECA et al., 1991).

É possivel, dentro de certos limites, aumentar a produção pesqueira mundial. No entanto, a população carente obteria benefícios imediatos se medidas fossem tomadas para a redução das perdas pós-captura (SURIMI, 1994).

Nos países desenvolvidos predomina a forma de consumo de pescado congelado, cerca de $50 \%$ do total. Nos países em desenvolvimento, onde a tecnologia empregada é menos sofisticada, produz-se pescado salgado, seco e defumado. Estes países têm participado efetivamente da pesca mundial por estarem desenvolvendo sua 
infraestrutura de pesca, barcos, portos e centros de processamento. Nos últimos 20 anos, mais de 100 parques industriais filiaram-se aos 37 complexos transnacionais de 46 países em desenvolvimento, predominando a tecnologia japonesa. Dentre estes destacam-se Brasil, Peru, Tailandia, Burma, Marrocos, Kênia, Indonésia, Filipinas, Argentina e Uruguai (OETTERER, 1991).

0 parque industrial brasileiro de pescado se desenvolveu ao longo do litoral, principalmente nas regiões sul e sudeste que absorvem cerca de $60 \%$ da produção. A indústria produz para consumo direto o pescado fresco resfriado, o pescado congelado inteiro, eviscerado, em filé e em postas; o pescado salgado, prensado, defumado e seco e o pescado enlatado; para consumo indireto, produz farinha e óleo.

A produção brasileira de pescado que já atingiu 900 mil de toneladas, reduziu-se a menos de 700 mil toneladas. No entanto, considerando a extensa costa litorânea, os rios navegáveis, as represas das hidroelétricas e a região amazônica, que guarda $17 \%$ do total de água do mundo, além de mais de 2 mil espécies subexploradas, estima-se um potencial de 4 milhões de toneladas de pescado (OETTERER, 1991)

O principal produto de exportação brasileira de pescado é o camarão congelado destinado, principalmente, aos Estados Unidos e ao Japão. Lagostas congeladas rendem altas divisas. O Brasil importa o pescado salgado sêco, o bacalhau, principalmente da Noruega, a truta e salmão do Chile.

Segundo a FAO (1993), a produção brasileira em 1991 de pescado processado, na forma de congelado ou resfriado foi de 174.100 toneladas, de pescado salgado ou em salmoura e defumado, 22.100 toneladas, de conservas de pescado em 
geral, 52.700 toneladas e de crustáceos e moluscos congelados, 15.000 toneladas (FAO. Fishery..., 1993).

A situação do setor pesqueiro brasileiro está distante da ideal, pois a infraestrutura de distribuição comercial é inadequada, com excesso de intermediários, há predominância da pesca artesanal, dificuldade de conter estoques reguladores na pesca industrial, riscos pela falta de campanhas que estimulem o consumo, má distribuição das unidades processadoras, baixa qualidade do pescado como matéria prima com prejuízo para o produto industrial, pouca diversidade dos produtos industriais e praticamente nenhuma utilização dos resíduos (ANDRADE, 1989; OETTERER, 1991).

\subsection{Resíduos de Pescado}

O termo resíduo refere-se a todos os subprodutos e sobras do processamento de alimentos e são de valor econômico relativamente baixo. A necessidade de se montar sistemas de aproveitamento dos resíduos das indústrias é de ordem econômica e de conservação de energia. Pode-se pensar desde um maior uso da matéria prima até o produto final ou ainda, o desenvolvimento de novos produtos que utilizem resíduos líquidos e sólidos no preparo. Para o aproveitamento destes resíduos as ferramentas mais úteis são as enzimas e os microrganismos (SHOEMAKER, 1986). 


\subsubsection{Tipos de resíduos}

No passado não havia a preocupação com a eficiência na utilização da proteína de descarte, e os resíduos não aproveitáveis se destinavam à fabricação de rações ou eram totalmente descartados. No caso de pescado, o material residual pode se constituir de aparas da "toalete" antes do enlatamento, carne escura, camarões fora do tamanho para descasque manual ou mecânico, cabeças, carcaças e efluentes em geral. Algumas pesquisas objetivaram o preparo da polpa de pescado com estes resíduos (LISTON, 1977; MORAIS \& MARTINS, 1981).

Uma estratégia atrativa para a utilização de resíduos é a reciclagem para a produção de biomassa. Os agentes biológicos mais utilizados para a produção de biomassa para adubo são microrganismos: bactérias e fungos e algas (SEAL, 1992).

Os resíduos de pescado, junto aos postos de beneficiamento e comercialização, causam sérios problemas de poluição ambiental, pois nem sempre é viável o transporte dos mesmos para as fábricas de processamento de farinha. Um método simples e de baixo custo para o aproveitamento desses resíduos é a silagem (NUNES, 1992).

Dos tipos de resíduos utilizados nos Estados Unidos, o mais comum se constitui da descarga junto com a água (há um número significativo de água residual proveniente das várias etapas do processamento, e em muitos Estados já existem leis que exigem o tratamento). A principal dificuldade encontrada neste tratamento está nas características dos resíduos: grande volume, médio a alto DBO (Demanda Biológica de 
Oxigênio) e sólidos em suspensão, além de altos níveis de gordura e proteína (JONES, 1974).

Um trabalho desenvolvido na Sumatra relata que os elasmobranquios contribuem com a maior porção da pesca da costa marítima e que a maior desvantagem associada a eles é a presença de uréia que limita comercialmente sua utilização. Há, em todo o mundo, muitas outras espécies de pescado que podem prover proteína de alta qualidade e que são subutilizadas (pequeno tamanho, carne escura, alto conteúdo de gordura, forte aroma, propriedades inaceitáveis de textura e outros fatores); mas que, podem ser usadas adequadamente como produtos resultantes de processos tecnológicos combinados (KARMAS \& LAUBER, 1987; SANKAR \& SOLANKI, 1992).

MAHARAJ \& RECKSIEK (1991), relatam que a costa marítima noroeste da América do Sul que se estende da Venezuela ao oeste do Rio Amazonas é uma zona altamente produtora de pescado. Mencionam que, em 1984, a produção de camarões foi de 20 mil toneladas. Em contrapartida, dão uma estimativa de que uma média de 2 mil toneladas de produto de pesca foram descartados.

As vísceras de peixes representam problemas para a indústria de pesca na Noruega. Estima-se que 20 a 25 mil toneladas de vísceras de pescado, que representam aproximadamente $50 \%$ do teor total de vísceras de bacalhau, "saithe" (Pollachius virens) e eglefim (Gadus aeglefinus), estão sendo descartadas nas fábricas (STROM et al., 1979).

Na Indonésia, estima-se um mínimo de 225 mil toneladas de refugos de peixes que são devolvidos ao mar e cerca de 200 mil toneladas de peixes que não podem 
ser utilizados devido a deterioração ou injúrias. Resíduos do processamento somam 25 mil toneladas. Estes grandes teores de resíduos disponíveis estão dispersos por todo o país e a disponibilidade em alguns lugares é pequena para suportar uma planta moderna que opere o ano todo (KOMPIANG, 1981).

Segundo TEUTSCHER (1986), grande parte da captura marinha não é utilizada para consumo humano, por motivos econômicos, como também por constituir de captura acompanhante devolvida ao mar, ou ainda, devido às perdas que ocorrem durante o envio à terra, no transbordo e na elaboração industrial.

No caso do bacalhau da Noruega, em uma produção de $450 \mathrm{mil}$ toneladas, seguem 250 mil para consumo humano; os subprodutos somam 40 mil toneladas de vísceras e 160 mil de cabeças, aparas e ossos (ALMAS, 1989).

O aproveitamento das sobras de vôngoles como matéria prima para "minced", "chopped" e "strips", além de ingredientes de "flavour" para preparo de sopas e "snacks", já vem sendo feito em escala comercial. Resíduos de fabricação de farinhas de peixes podem ser submetidos a fermentação fúngica e transformados em ração insenta de resíduos tóxicos e de lipídios oxidados (HOOD \& ZALL, 1980; HOSSAIN et al., 1987).

As cabeças de camarão correspondem a cerca de 40 a $50 \%$ do seu peso total e apresentam problemas no congelamento industrial. Os resíduos podem ser recuperados para fabricar ração ou camarão solúvel que vem sendo usado para substituir $5 \%$ da fonte de proteína na dieta de camarões em cativeiro. 0 sabor e os componentes voláteis das cabeças de camarão são recuperados por digestão enzimática, concentração 
e "spray drying". O material solubilizado constitui de 9 a $12 \%$ de aminoácidos e apresenta componentes sulfurados, cetonas, aldeídos, álcoois, ésteres, hidrocarbonetos, pirazinas, piridinas, amidas, aminas e outros (TENUTA FILHO, 1983; PAN, 1989).

A fauna acompanhante da captura de camarão, constitui uma mistura de espécies de diversas formas e tamanhos de baixo valor comercial; vem sendo estudada para fabricação de farinha e pode ser encaminhada para preparo de silagem (OTTATI et al., 1990; RODRIGUEZ et al., 1990a e b).

\subsubsection{Aproveitamento de resíduos}

Segundo GREENSHIELDS (1992), a idéia de reciclar resíduos, particularmente de alimentos, não é nova, a exemplo da recuperação do vinho como vinagre. Entretanto os conceitos e motivos que dirigem as idéias para a utilização dos resíduos são vários, muitas vezes têm vida curta e frequentemente são tidos como desperdícios de investimentos.

Os aspectos científico e tecnológico são preteridos aos econômicos e políticos, que têm mais força. Hoje, com o domínio da biotecnologia, espera-se uma reversão de conceitos. Um levantamento feito em 1992, em pesquisa e desenvolvimento na área de tecnologia de alimentos na Inglaterra, revelou que as áreas da tecnologia de alimentos para a próxima década, de alto nível de prioridade, são, entre outras, novos processos usando enzimas, recuperação de subprodutos e controle da poluição. $\mathrm{O}$ ideal será utilizar a matéria-prima em toda a sua extensão, recuperar os subprodutos e assim 
evitar a própria obtenção do resíduo.

O aproveitamento das sobras comestíveis das operações tradicionais de filetagem ou de corte em postas de pescado assume importância muito grande, pois além de abaixar os custos dos insumos principais, minimiza os problemas de poluição e o custo unitário das matérias-primas, quando comparado aos dos produtos acabados (LISTON, 1977; MORAIS \& MARTINS, 1981; TENUTA FILHO, 1983; OETTERER et al., 1992).

A forma mais racional de se utilizar o potencial pesqueiro é recuperando mais as partes comestíveis dos peixes capturados, como as aparas após a retirada da parte esquelética que podem se transformar em "minced fish"; 20 a $30 \%$ da captura acabam sendo descartados, nesta operação. Há busca de novos mercados para novos produtos como os concentrados protéicos, os isolados protéicos, as proteínas texturizadas, etc (HORISBERGER, 1979).

No Brasil, segundo LAJOLO (1984), estuda-se como material residual da industrialização, bagaço de cana, palha de arroz, trigo, sabugo de milho, soro de leite, polpa, mucilagem e cascas de café e do cacau, melaço, resíduos da industrialização de frutas, vinhoto de cana e de mandioca, resíduos da fermentação de monoglutamato, entre outras. Neste trabalho, não há referência ao estudo dos resíduos da industrialização do pescado; há porém, a possibilidade de aproveitar estes resíduos como já ocorre com os vinhotos provenientes da fermentação de antibióticos, de monoglutamato, de cervejas e da obtenção de enzimas via bioconversão microbiana. 


\section{Para a UNITED NATIONS INDUSTRIAL DEVELOPMENT} ORGANIZATION - UNIDO (1991), a recuperação e a utilização de resíduos tanto sólidos quanto líquidos, de pescado marinho, pode ser uma medida segura de proteção ao ambiente e à indústria. Assim, a UNIDO realizou, em 1991, um amplo estudo com informações técnicas e custos relativos ao gerenciamento dos resíduos da indústria processadora de pescado.

Várias opções são discutidas, como as produções de ração, silagem e "minced". A silagem, por exemplo, é sugerida como uma opção para operações em pequena escala. $O$ resíduo pode ser adicionado de carboidratos como o melaço ou pode ser liquefeito pelo uso de ácidos orgânicos. A silagem pode ser produzida em partidas pequenas de $50 \mathrm{Kg}$ ou em grandes tanques de 1 tonelada ou mais. Como boa fonte protéica, a silagem de pescado pode substituir as farinhas de peixe e de soja na dieta de animais (UNIDO, 1991).

Alguns pesquisadores têm estudado a possibilidade do emprego de sucos de frutas associados ou não a utilização de ácidos para o tratamento de resíduos de origem animal, incluindo o pescado. As propriedades bioquímicas e microbiológicas dos produtos foram consideradas adequadas por períodos de até seis meses em experimentos com suco de tamarindo associado ao ácido acético. A carne líquida de frango, de vaca ou de peixe pode ser produzida com a urilização de suco de abacaxí para fracionar a proteína (BACHANAN et al., 1992).

Para BIMBO \& CROWTHER (1992), da produção de pescado e moluscos que é de cerca de 100 milhões de toneladas por ano, apenas $28 \%$ são 
processados como alimento e óleo. Os autores revelam que pressões econômicas feitas em regiões pobres, baixos preços nas regiões tradicionalmente produtoras, e alto custo dos combustíveis forçaram a indústria a buscar novos mercados e produtos que possam tirar vantagem dos conteúdos protéico e de gordura do pescado.

GURGEL \& FREITAS (1973), em trabalho onde avaliam o aproveitamento do pescado do nordeste brasileiro e analisam as perdas com o processamento e a possibilidade do aproveitamento dos resíduos para a elaboração de subprodutos, informam que os peixes de pequeno tamanho como a sardinha, o "branquinho" e o "cangati", têm rendimentos baixos, de 62,1\%, 59,6\% e 68,7\%, respectivamente.

Stamby (1963) ${ }^{1}$, citado por GURGEL \& FREITAS (1973), afirma que, na maioria das espécies de peixes, há um aproveitamento de cerca de $65 \%$, depois de eliminadas a cabeça, as nadadeiras, as escamas e as vísceras. Desse estudo, destacam-se duas conclusões: a porcentagem dos desperdícios dos peixes de água doce do nordeste, em relação ao peso vivo, variou de $20,5 \%$ a $53,4 \%$ e os desperdícios do pescado beneficiado, poderão ser aproveitados para a elaboração de subprodutos de fabricação doméstica, ou até mesmo industrial.

FREITAS \& GURGEL (1976) publicaram trabalho sobre o aproveitamento de resíduos do pescado dos açúdes do nordeste, onde destacam que as vísceras do pescado capturado são totalmente desperdiçadas, quando poderiam ser utilizadas na elaboração de subprodutos não comestíveis. Em 1975 estudaram 23 espécies

${ }^{1}$ STAMBY, M.E. Industrial fishery technology, Reinhold Publishin Corp., 1963. 393p. 
de peixes de água doce, quando os autores observaram que, após beneficiadas, as vísceras constituiam cerca de $11 \%$ do peso total, sendo de 1.606 toneladas a quantidade deste material desperdiçado naquele ano, naquela região.

Conforme informações do Ministério da Indústria e Comércio brasileiro, em estudo de 1985, sob o aspecto de aproveitamento de resíduos, a indústria de pescado representa um potencial, pois seus descartes podem facilmente ser transformados em produtos com grande aproveitamento mercadológico, como a farinha. Os resíduos obtidos da produção brasileira de pescado enlatado, cerca de $50 \%$ do peso do peixe inteiro, poderão ser transformadas em farinha para consumo animal e óleo para produção de tintas, vernizes e acabamento de couros (BRASIL. Ministério..., 1985).

O processamento do pescado nos Estados Unidos rende, além do alimento em si, outros produtos como o óleo e os subprodutos. No caso da industrialização do "menhaden" ou savelha (Brevoortia tyrannus), o material remanescente do processamento é levado à cocção e prensagem para a extração do óleo. A água remanescente é separada dos resíduos sólidos e evaporada para a produção de um concentrado solúvel. O resíduo sólido é seco até atingir cerca de $10 \%$ de água e é incorporado à farinha para ração. No caso do atum enlatado, as vísceras são removidas e usadas para preparo de rações e o fígado é usado como fonte de óleo e de vitaminas. A carne escura é separada e utilizada para ração. $O$ mesmo ocorre no caso do salmão (Oncorhynchus sp.) e do atum (Thunus sp.) (JONES, 1974).

Algumas empresas americanas vêm aproveitando material residual liquefeito da industrialização do pescado para obter fertilizante em projetos combinados 
com a redução de pesticidas; apesar do custo ser maior do que os outros fertilizantes, acredita-se que com a divulgação, aumento de volume utilizado e desenvolvimento de novas técnicas de concentração, o custo será diminuído. A política é fazer com que todo empresário de pesca dê um destino ao material residual para que este seja uma nova fonte de renda (REGENSTEIN, 1990).

A biomassa marinha da Noruega vem sendo utilizada para produzir meios de cultura e produtos bioquímicos. Essa biomassa é antes de mais nada uma fonte de proteínas. No passado estas proteínas marinhas eram utilizadas diretamente como alimento humano, ou processadas como ração e óleo. Mas há um mercado mais refinado para estes produtos de diferentes aplicações, como por exemplo, a fabricação de meios de cultura que podem ser utilizados para fermentação. As peptonas maninhas tem dado bons resultados como meios para crescimento de microrganismos marinhos. As enzimas digestivas que estão sendo produzidas a partir das vísceras de pescado são a pepsina, a tripsina e a quimiotripsina; a produção de hidrolisados protéicos de pescado é baseada na hidrólise promovida pelas enzimas do próprio tecido e das adicionadas. (ALMAS, 1989).

A pesca recreativa no Estado de Minnesota, recolhe anualmente, 13.608 toneladas de pescado e, pelo menos, metade desse número significa resíduos. Trabalho utilizando compostagem desses resíduos e subsequente avaliação estatística dos custos, mostrou resultados promissores (SMALL-SCALE..., 1992).

De acordo com um programa desenvolvido em 1990 pelo Estado de Michigan, E.U.A., que tinha como objetivo livrar áreas de pesca por esporte e de pesca 
para transformação industrial das carcaças e resíduos indesejáveis ali deixados, adotou-se a silagem que se mostrou plenamente satisfatória. Foram oferecidas aos usuários remunerações pelos resíduos e a planta foi instalada. Após 6 a 8 semanas do início do processamento as carcaças tinham sido desfeitas e o odor era agradável (COMPOSTING fish..., 1991).

Em 1990, durante "Workshop" promovido pelo IFT - Institute of Food Technologists sobre resíduos de pescado, relatou-se que na Europa muitos pesquisadores têm feito silagem para cultura de peixes, e em particular na Alemanha estudou-se a compostagem em termos de redução de volume (50-75\%) a redução de DBO (90\%), além da eliminação de odores e controle de patógenos (INSTITUTE of Food..., 1992).

Dentro da mesma linha uma pesquisa canadense sobre compostagem de resíduos de alimentos é muito otimista quanto às aplicações futuras. Relata que as comunidades locais tiveram interesse em cooperar e que o produto final teve um custo baixo. $\mathrm{O}$ autor traçou um paralelo com os modelos europeus de compostagem de resíduos orgânicos (SPENCER, 1990).

Para FREDERICK (1992a e b), o processamento comercial de pescado perfaz mais de 1.400 toneladas de resíduos anualmente no Estado de Wisconsin, Estados Unidos, com o agravante de que a pesca, provavelmente, produz quantidade equivalente. Baseado nesses dados, o autor coordenou um projeto para avaliar a viabilidade econômica da compostagem de resíduos de pescado com pó de serra. O material só ficou pronto para o teste de mercado dois anos após (a madeira sob as condições utilizadas precisou desse tempo para se decompor) e a avaliação final do autor foi de que, em 
pequena escala, a compostagem como negócio é atrativa, mas lucrativamente desvantajosa em escala industrial em função do custo do transporte dos grandes volumes utilizados a grandes distâncias. Assim, o autor recomenda que a planta de produção esteja próxima à área de consumo.

Ainda, o mesmo autor resume os trabalhos realizados e discutidos na "National Fisheries By-products Composting Conference" em outubro de 1991, no Estado de Wisconsin. Assim, sabe-se que na Flórida um trabalho realizado com carcaças e resíduos da lagosta azul conseguiu reduzir em $17 \%$ o volume do descarte; a Universidade de Minnesota - Duleith estima que até o final do ano, cerca de cem unidades para compostagem de resíduos de pescado devem ser construídas; um processo simplificado de tecnologia vem sendo desenvolvido para processar lagostas; a Universidade de Columbia tem desenvolvido plantas e assegurado recursos para construção de locais para compostagem piloto; a Universidade de Washington tem produzido quatro tipos de compostos com resíduos de pescado e camarão variando o material adicionado.

Resíduos do processamento da lagosta azul podem ser compostados aerobicamente com a adição de uma fonte de carbono, como palha de trigo e agentes que controlem o pH como sulfato ferroso levando a um produto estável.

DISNEY et al. (1977), em trabalho que pretendeu traçar um panorama mundial do desenvolvimento de silagens destacou que houve um renovado interesse em silagem de pescado utilizando resíduos. Nesse trabalho, o autor discutiu ainda a possibilidade de utilização de outros resíduos não convencionais e deu particular ênfase 
à pequena escala de pesca e conservação de valiosos suplementos protéicos.

A importância do aproveitamento de resíduos da industrialização do pescado, bem como o atual estado da arte deste assunto, podem ser vistos nas recomendações do "43 ${ }^{\text {rd }}$ Annual Meeting Pacific Fisheries Technologists", realizado em 1992 na Califómia, Estados Unidos, onde foram discutidos os trabalhos em andamento nesta área. Assim, N. Hendenson (Rutgers University - New Jersey) demonstrou as tendências da utilização de resíduos na indústria de processamento de mexilhões no Estado de New Jersey; S. Andree (Florida Sea Grant) dissertou sobre o preparo de compostagem na região de Big Bend do Estado da Florida utilizando vísceras de mexilhões e caranguejos; J. Cato (Florida Sea Grant) comentou sobre as técnicas de preparo de composto utilizando resíduos sólidos do processamento de pescado marinho; T. D. Harrison (Virginia Tech) caracterizou os resíduos sólidos e líquidos nas fábricas de processamento de caranguejos e discutiu a habilidade das indústrias para atingir o aproveitamento integral dos efluentes; D.P. Green e S. Hudson (North Caroline State University) explicaram a metodologia de aplicação das técnicas de prevenção da poluição para redução de resíduos e discutiram o desenvolvimento de filmes e fibras a partir da quitina e seus derivados (INSTITUTE of Food..., 1992).

No Brasil, alguns trabalhos sobre o aproveitamento de resíduos de pescado, em experimentos de laboratório, foram apresentados no XIII Congresso Brasileiro de Ciência e Tecnologia de Alimentos. Assim, NUNES, 1992, (UFPB Paraiba) preparou silagem com utilização de ácido acético; VIEIRA et al., 1992 (UFCCeará) fez a avaliação biológica do hidrolisado preparado com subprodutos da lagosta, 
visando obter peptona; SALES et al., 1992 (DEPAN/FEA - São Paulo) apresentou alguns indicadores de qualidade protéica e dietética, bem como os efeitos da complementação protéica da dieta comercial com silagem de tilápia e OETTERER et al., 1992 (ESALQ/USP - São Paulo) apresentaram experimentos sobre a possibilidade de produção de silagem ácida, enzimática e microbiológica com resíduos do processamento do pescado de água doce.

\subsection{Silagem de pescado}

\subsubsection{Definições}

A silagem é um produto líquido preparado com pescado inteiro ou picado, ou parte dele, ao qual tenham sido adicionados ácidos e a liquefação da massa tenha ocorrido, inclusive pela ação das enzimas já presentes no pescado. O produto líquido, pode ser obtido por outras vias, porém o princípio é o de que as enzimas presentes após a moagem da massa, são difundidas uniformemente e a sua ação é favorecida pela acidez através do uso de ácidos; estes também agem inibindo a ação microbiana. A silagem é tradicionalmente usada como alimento para animais e pode ou não conter gorduras (TATTERSON \& WINDSOR, 1974; BROWN \& SUMNER, 1985; HALL, 1992).

A silagem de pescado se constitui em um produto líquido preservado pela ação de ácidos (silagem química) ou por fermentação microbiana induzida por 
carboidratos (silagem biológica) e pode ser feita a partir do pescado inteiro ou do material residual do pescado. A liquefação é conduzida pela atividade de enzimas proteolíticas naturalmente presentes nos peixes ou adicionadas (silagem enzimática) (KOMPIANG, 1981).

O princípio envolvido na manufatura da silagem é o de que as enzimas já presentes são incorporadas à massa através da moagem; o ajuste do pH favorece a rápida ação dessas enzimas inibindo a ação das bactérias. Produtos liquefeitos de pescado podem ser obtidos de outras maneiras, por exemplo, pela adição de enzimas ou pela adição de bactérias produtoras de ácido lático (TATTERSON \& WINDSOR, 1974).

HAARD et al. (1985), em trabalho que trata da estabilização da proteína e do óleo em silagem de pescado para a suplementação alimentar de ruminantes, definem silagem como sendo o produto liquefeito obtido de resíduos de pescado que são cortados e misturados com ácido, as enzimas presentes no pescado quebram a proteína, enquanto a acidez previne a deterioração microbiana.

\subsubsection{Produção e utilização da silagem}

GREENSHIELDS (1992) traça um panorama dos processos tecnológicos para a produção de alimentos e utiliza o conceito de biotecnologia como um marco divisório entre os "antigos conceitos" e os "novos conceitos" que lançam mão da bioengenharia das enzimas e dos microrganismos, levando à ausência ou diminuição da poluição ambiental. O autor acredita ser possível a obtenção de produtos com resíduos 
animais reciclados pela adição de outros componentes utilizando o sistema da natureza.

Sabe-se que no passado não houve grande preocupação com a eficiência na utilização de proteína residual, aceitando-se grandes perdas, na forma de resíduos ainda aproveitáveis, como resultado final de uma dada operação no processamento de pescado. Tais resíduos tem sido, então, destinados à fabricação de rações animais ou descartados (HORISBERGER, 1979).

Segundo TATTERSON \& WINDSOR (s.d.), o primeiro trabalho sobre silagem foi feito na Suécia em 1930, e a Dinamarca iniciou a primeira produção comercial dez anos depois.

A silagem de pescado é produzida na Dinamarca, Noruega, Polônia e demais países da Europa (HAARD et al., 1985).

Em escala comercial a silagem vem sendo produzida na Polônia e na Dinamarca desde os anos 60, para a produção de alimentos para aves e suínos ou incorporada a rações como complemento protéico, compondo alimentos para animais domésticos e peixes provenientes da aquacultura. Na França está sendo produzido um hidrolisado protéico de pescado desossado com $90 \%$ de proteína, e que alcança US\$ 1,500 por tonelada. Na Indonésia, a silagem é produzida em escala experimental e utilizada em rações que susbtituem a farinha de peixe e a de soja na alimentação de suínos, peixes e aves. Apesar de comum nos países escandinavos, onde são utilizadas há muitos anos com sucesso, a produção industrial da silagem é limitada devido ao alto teor de umidade, o que toma difícil o transporte do produto a longas distâncias. Pode-se obter produtos na forma de pasta como na Austrália, aproveitando as vísceras de abalone 
ensiladas com cereais em grão. O sabor e a aceitabilidade de cames de frangos alimentados com silagem foram considerados adequados pelos consumidores (KOMPIANG, 1981).

A silagem é usada na alimentação animal da mesma forma que outros alimentos na forma líquida ou desidratada. É indicada em criação de suínos, que utiliza sistema líquido de alimentação em função da qualidade e do "flavour". Outros animais como vacas leiteiras e galinhas, têm se alimentado com bons resultados (TATTERSON \& WINDSOR, s.d.).

A silagem de pescado é largamente usada na Escandinávia na alimentação de animais e peixes dado o seu alto valor nutritivo (igual ao da matériaprima que lhe deu origem), mesmo durante longos períodos de armazenamento, aliado ao seu baixo custo (MANIKANDALEVU et al., 1992; DAS et al., 1993).

A adição de silagem de pescado foi considerada uma maneira efetiva de enriquecer as rações de suínos, uma vez que grande quantidade de proteína bruta é absorvida, sendo portanto, a silagem de pescado comparável à silagem vegetal (HAARD et al., 1985).

Na Finlândia, os resíduos de trutas são armazenados como silagem pela adição de ácido fórmico, é usada em estado líquido para a alimentação de peixes, porém se devidamente seca pode ser armazenada, transportada e usada de forma mais fácil e flexível (DAS, et al., 1993).

A silagem líquida de pescado é fonte de proteína de alta qualidade e de minerais para a alimentação animal; é versátil, e pode ser utilizada como suplemento da 
ração de vários animais como peixes, suínos, ovelhas, gado e aves domésticas (HAARD et al., 1985).

A silagem de pescado é consumida em maior escala como alimento para animais, aves e suínos, ou incorporada a rações como suplemento. Cada $100 \mathrm{Kg}$ de matéria seca de silagem tem $19,41 \mathrm{Kg}$ de proteína crua digestível e $53,79 \mathrm{Kg}$ de nitrogênio digestível; contém vitaminas $\mathrm{B}_{1}, \mathrm{~B}_{2}, \mathrm{~B}_{12}$, ácido pantotênico e ácido nicotínico (ANDRADE, 1983).

Embora uma considerável quantidade de silagem líquida seja produzida na Europa, principalmente para a alimentação animal, nenhuma, por enquanto, é produzida nos trópicos. Mencionam-se alguns experimentos que estão sendo conduzidos, porém, mais informações são necessárias a respeito de experimentos nos países em desenvolvimento (DISNEY et al., 1977).

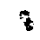

RODRIGUEZ et al., (1990b), ensilaram espécies que acompanham a captura do camarão na Venezuela, utilizando uma mistura de ácido sulfúrico diluído e ácido fórmico concentrado na proporção de 1:4 por 17 dias. O produto foi analisado biologicamente em ratos e o resultado para a proteína foi similar ao grupo controle (caseína). $\mathrm{O}$ trabalho recomenda a utilização do ensilado como substituto da farinha de pescado e como fonte de proteína na alimentação de frangos de engorda em idade de crescimento.

KOMPIANG et al. (1980); McNAUGHTON et al. (1985), reportam que o uso da silagem desidratada e adicionada à dieta de frangos de engorda não ocasiona efeitos adversos no crescimento. 
DISNEY et al. (1977), citam outros autores para respaldar a opinião deles de que, para facilitar e baratear o custo da estocagem da silagem, deve ser feita uma secagem do produto. Sob as nossas condições, esta operação seria inviável comercialmente, uma vez que a prática de utilização regular do produto como alimentação animal ainda é incipiente. A expectativa, é a de produzir, no campo, uma silagem seca ao sol que seja adequada a um maior número de sistemas comerciais de produção animal, já que fontes de carboidratos podem ser incorporadas à silagem e depois desidratadas. Nessas condições a produção de silagem de pescado pode ser viável.

\subsubsection{Processamento da silagem}

O mecanismo que determina a liquefação da silagem está no papel das enzimas das vísceras que se difundem pela massa cárnea e são responsáveis pela hidrólise; porém peixes eviscerados também liquefazem, pela presença de enzimas dos tecidos (TATTERSON \& WINDSOR, 1974; KOMPIANG, 1981; STROM \& EGGUM, 1981; ANDRADE, 1983; ANDRADE, 1984; RODRIGUEZ et al., 1990a e b).

A taxa de liquefação depende do tipo de matéria prima, se fresca, e da temperatura do processo. Os peixes frescos e os peixes gordurosos liquefazem mais rapidamente. É importante que nas instalações haja condições para adição do ácido imediatamente após o material chegar à indústria; assim evita-se a liquefação lenta. Aquecer a mistura acelera o processo; a silagem, se mantida a $20^{\circ} \mathrm{C}$, leva em média 2 dias para liquefazer, se a $10^{\circ} \mathrm{C}, 10$ dias. Assim no inverno recomenda-se aquecer a 
mistura inicialmente (TATTERSON \& WINDSOR, s.d.; STROM \& EGGUM, 1981).

Durante o processo de ensilagem, as proteínas são hidrolisadas pelas enzimas e o nitrogênio se torna mais solúvel. A proteólise na pele e nas vísceras é maior nas primeiras 24 horas. $O$ teor de nitrogênio solúvel aumenta de 10 a $20 \%$ nos primeiros dias de estocagem a $23^{\circ} \mathrm{C}$. Após 10 dias, o aumento é de $75 \%$ e após 1 mês, de $85 \%$. Após 3 dias de silagem, $50 \%$ do total de nitrogênio está sob a forma não protéica e o teor de aminoácidos livres aumenta rapidamente durante os cinco primeiros dias (BACKHOFF, 1976; WINDSOR, 1979; STONE \& HARDY, 1986).

A silagem se liquefaz e uma separação mecânica pode isolar uma camada de lipídios, uma camada protéica aquosa e um sedimento insolúvel. Estas fases podem ser separadas por centrifugação. Às vezes é conveniente promover uma peneiragem para aliviar o trabalho da centrífuga. Após cerca de 2 semanas, $85 \%$ da proteína da silagem está em solução. A fenilalanina e particularmente a tirosina são levemente solúveis em solução aquosa. Em estocagem longa estes aminoácidos precipitam, devido ao fato de terem sido liberados na hidrólise protéica. Os teores de metionina e de lisina são altos após uma semana. Um aumento do NPU (Net Protein Utilization) se deve ao aumento do nível da lisina (WINDSOR, 1979).

Se as espécies utilizadas contém alto teor de lipídios, o óleo deve ser removido; esta operação é onerosa devido aos solventes. Após a autólise, a maioria dos lipídios, pode ser removida por centrifugação, ou após aquecimento a $95^{\circ} \mathrm{C}$ e centrifugação (WINDSOR, 1979). 
Geralmente, na prática, os lipídios não são separados. No caso do bacalhau da Noruega, o teor de lipídios das vísceras destinadas à silagem varia, dependendo da remoção manual do fígado, que é utilizado para produção de vitamina A. Ao se objetivar obter um produto de diferentes matérias primas, porém uniforme, convém pensar em um método rápido para remoção dos lipídios. Um teor aceitável de lipídios na silagem processada é de $0,5 \%$ para produtos comerciais (TATTERSON \& WINDSOR, 1974).

A silagem pode ser produzida com pescado semi gordo ou gordo. Nesse caso, é necessário remover a gordura em algum estágio da produção, uma vez que estas se deterioram rápido e um alto grau de oxidação produz perda de valor nutricional (TATTERSON \& WINDSOR, s.d.).

Acredita-se que o grau de hidrólise pode ser usado como um critério químico para avaliar a silagem de pescado. A hidrólise das proteínas em pequenos peptídios e aminoácidos livres, torna-as mais utilizáveis para a biossíntese, do que as proteínas intactas (ESPE et al., 1989).

Embora a liquefação da silagem se complete em 2 ou 3 dias, a proteína da silagem de pescado é continuamente hidrolisada por pelo menos um mes (HAARD et al., 1985).

Tão importante quanto conhecer a composição da silagem, é conhecer as mudanças químicas que ocorrem durante o armazenamento. Para DISNEY et al. (1977), a liquefação é entendida como uma autólise, mais predominantemente, a proteólise, cujos resultados aparecem muito rapidamente, cerca de uma semana, quando 
$70 \%$ do nitrogênio presente se torna solúvel. O mesmo autor mostra que tais alterações são dependentes da temperatura e favorecidas a $30^{\circ} \mathrm{C}$.

\subsubsection{Estocagem da silagem}

A silagem de pescado mantida sob correta acidez, permanecerá à temperatura ambiente por pelo menos dois anos sem deterioração. A silagem comercial deve ficar estocada pelo menos 6 meses antes da comercialização, pois poderá desenvolver melhor consistência e apresentar aroma agradável (TATTERSON \& WINDSOR, s.d.).

Sob estocagem, na silagem de peixe, há um aumento de amônia e de ácidos graxos livres, porém pequeno. A estabilidade da silagem dependerá da manutenção do pH abaixo de 4,5, conforme o ácido utilizado. A preservação se mantém por mais de um ano e o aroma desprendido é ácido. $O$ índice de acidez em ácidos graxos na silagem oscila entre 50 e 60 o que corresponde a cerca de $20 \%$ de ácidos graxos livres. Quanto aos aminoácidos, após longa estocagem há diminuição do triptofano, o que diminui o valor biológico da silagem, porém o teor de lisina permanece (BACKHOFF, 1976; GILBERT \& RAA, 1977; STROM et al., 1979).

A viscosidade da silagem depende do conteúdo de vísceras e do conteúdo de óleo, mais do que da solubilidade da proteína. Os oligopeptídios aumentam com rápido declínio da viscosidade (HAARD et al., 1985). 
DISNEY et al. (1977) resumem as mudanças que ocorrem com os lipídios durante o armazenamento da silagem. Mencionam que o aumento do conteúdo de ácidos graxos livres, indica hidrólise dos glicerídeos, enquanto mudanças oxidativas causam escurecimento; um teor de até $3 \%$ de ácidos graxos livres é desejável. Os autores recomendam que para manter a qualidade do produto deve haver uma rápida remoção da gordura, pois as maiores tranformações ocorrem no início do processo e são dependentes da temperatura.

No entanto, além de 90 dias de estocagem da silagem, esta perde parte do seu valor nutricional devido a reações entre os componentes da hidrólise de proteínas, como pequenos peptídios e aminoácidos livres; também a saponificação pode contribuir para a diminuição da qualidade. A adição de formaldeído após a liquefação se completar serve para prevenir a hidrólise contínua e a rancificação. Este componente também diminui o desenvolvimento de odores estranhos e a formação de bases voláteis. Este procedimento é recomendado para uso da silagem de pescado em mistura com forragem, na alimentação de ruminantes. Outros aditivos são recomendados no preparo da silagem como o sorbato de potássio, para evitar o desenvolvimento de fungos. Quando a silagem é preparada sem a adição do sorbato de potássio, pode aparecer na superfície um visível crescimento de fungos e leveduras (HAARD et al., 1985; ESPE et al., 1989; RAA \& NJAA, 1989; LEVIN \& WITKOWSKI, 1991).

KOMPIANG (1981), quando discute o valor nutricional, menciona que a silagem supre aos animais de teste a porção protéica, similarmente à dieta controle. Destaca que a eficiência de conversão se torna baixa e o valor nutricional é também 
afetado negativamente com o aumento do tempo de estocagem. Para ele, há uma relação direta do escurecimento provocado por reações dos lipídios com a perda do valor nutricional.

\subsubsection{Valor nutricional}

A composição da silagem de pescado é muito semelhante a do material que lhe deu origem. A composição do material residual, por exemplo, de pescada branca (Urothycis tenuis) é de cerca de $80 \%$ de umidade, $15 \%$ de proteína, $4,5 \%$ de cinza e 0,5\% de lipídios. A silagem de pescado ao ser usada como ração da mesma forma que a farinha de pescado, será fonte de $15 \%$ de proteína, quando a farinha tem cerca de 65\%. Portanto, a melhor utilização da silagem é para a alimentação de suínos, uma vez que pode ser utilizada na forma líquida (KOMPIANG, 1981).

A composição final da silagem varia consideravelmente com o tipo de matéria prima empregada, particularmente quanto ao teor de lipídios que é variável com a estação de captura (BROWN \& SUMNER, 1985; HAARD et al., 1985).

O valor nutritivo da silagem pode ser alterado de acordo com o grau de frescor da matéria-prima, condições de armazenamento e contaminação prévia à ensilagem, alterando sua qualidade nutricional. Tomadas as devidas precauções na manipulação do peixe antes e durante o processo de ensilagem, esta pode ser incorporada na dieta de frangos de engorda sem causar alterações no crescimento e no sabor da came; o teor máximo de suplementação deve ser de 10\% (JOHNSON et al., 1985). 
DISNEY et al. (1977), ao avaliarem a composição aproximada da silagem de pescado, relatam que esta é a mesma da matéria-prima, apesar da pequena diluição provocada pela adição do ácido, e que se altera com a retirada do óleo, aumentando os componentes na proporção do óleo removido.

Apesar das alterações previstas nas estruturas físicas e químicas do peixe, o valor nutricional da silagem é semelhante ao da matéria-prima, podendo ser estocada comercialmente por 6 meses (TATTERSON \& WINDSOR, s.d.).

O valor nutricional da silagem está, principalmente, na digestibilidade protéica elevada e na presença de lisina e triptofano entre outros aminoácidos essenciais (OETTERER et al., 1992).

O valor nutricional da silagem deve ser preservado, evitando-se estocagem prolongada do produto. O grau de hidrólise deve ser utilizado como um critério químico da qualidade para a silagem, pois ao haver a autólise e em seguida a rancificação, o produto fica prejudicado. Análises de sabor e aceitabilidade da carne de frangos alimentados com silagem incorporada à ração mostraram a viabilidade do produto (ESPE et al., 1989; RAA \& NJAA, 1989).

STROM \& EGGUM (1981), avaliaram nutricionalmente, através de ensaio biológico, silagem de pescado preparada com vísceras e uma mistura 1:1 de ácidos fórmico e propiônico, a uma concentração final de $1,5 \% \mathrm{p} / \mathrm{v}$, e concluiram que o valor nutricional da silagem aumentou após estocagem e remoção de lipídios, produzindo um aumento da utilização da proteína bruta (NPU) de 60 a 70\%. Os autores consideraram que o aumento do NPU pode ser atribuido principalmente ao aumento do 
nível de lisina e que no experimento a histidina não foi identificada como um fator limitante.

Tal idéia é rebatida por STONE \& HARDY (1986), que afirmam que a silagem "fresca" é nutricionalmente superior a silagem estocada e mantida a pH 2,0, uma vez que os peptídios são melhor absorvidos que os aminoácidos livres, a amônia e os produtos de degradação acumulados no decorrer do período de autólise.

Para ESPE et al. (1989), o valor nutricional da silagem fresca foi melhor que a estocada em experimentos feitos com ratos. A digestibilidade e a utilização da proteína são maiores na silagem fresca do que na silagem estocada (com mais de 90 dias a proteína é pouco utilizada pelos ratos) como consequência da autólise e rancificação da silagem.

TATTERSON \& WINDSOR (1974), quando discutem sobre alguns aspectos nutricionais da silagem estocada, dizem que estudos das modificações do nitrogênio solúvel indicam que ocorre uma rápida quebra nas proteínas para peptídios de baixo peso molecular e aminoácidos livres. Após 30 dias de estocagem, cerca de 75 a $85 \%$ do total do conteúdo de nitrogênio se torna solubilizado. Os autores ressaltam que o óleo contido na silagem após estocagem tem um alto teor de ácidos graxos livres.

BACKHOFF (1976) monitorou as transformações químicas ocorridas em silagem de bacalhau preparadas com vísceras, pele e outras partes, durante a estocagem. O autor verificou a formação de nitrogênio não protéico (aminoácidos livres, bases voláteis e polipeptídios) e destacou perda de triptofano com manutenção do teor de lisina. 
Na produção de silagem química os aminoácidos são basicamente estáveis, a tiamina é muitas vezes degradada pela tiaminase, produzida durante o processo de ensilagem (HALL, 1992).

\subsection{Silagem química de pescado}

A silagem ácida de resíduos de pescado foi desenvolvida originalmente a partir de um método patenteado por A.I. Virtanen em 1920, que utilizava ácidos sulfúrico e clorídrico e o produto era neutralizado com carbonato de cálcio (DISNEY et al., 1977).

\subsubsection{Uso dos ácidos}

O uso de ácido fórmico para preservação de material residual destinado às rações se iniciou após a Segunda Guerra Mundial.

Segundo DISNEY et al. (1977), na preparação de silagem ácida, a escolha do agente de preservação deve recair entre um ácido mineral, mistura de ácidos minerais, ácidos orgânicos, como o fórmico e o propiônico, ou mistura de ácidos inorgânicos e orgânicos. $O$ autor complementa dizendo que a utilização vai depender do custo e da avaliação do ácido e das condições em que o produto será preparado. $O$ ácido fórmico é mais caro que os ácidos minerais comuns, mas produz silagens que são menos ácidas e não requerem neutralização antes do uso. 
KOMPIANG (1981), da mesma forma, considera que na preparação da silagem química, a escolha do agente preservante deve recair entre o ácido mineral, a mistura de ácidos minerais, os ácidos orgânicos ou uma mistura de ácidos minerais e orgânicos. A mistura dos ácidos fórmico e propiônico tem sido recomendada. Têm sido demonstrado também que os constituintes da carcaça do peixe são um fator importante na escolha do ácido e sua quantidade.

STROM et al. (1979), em estudos com silagem, chegaram à conclusão de que a mistura de ácidos fórmico e propiônico, além de produzir uma boa silagem, inibe o crescimento de fungos, incluindo o $A$. flavus, principalmente quando se prepara silagem em países tropicais.

Ácidos orgânicos, como o ácido fórmico são geralmente mais onerosos do que ácidos minerais, mas produzem silagens menos ácidas (pH 4,0 a 4,5) e que não exigem neutralização antes do uso. Acidez muito forte (pH 2,0) é necessária quando ácidos minerais são usados. Tal fato mostra que a preservação não depende somente da acidez e que se o ácido tem uma forte ação bactericida, misturas com pH mais alto são aceitáveis (KOMPIANG, 1981).

Em trabalho desenvolvido na Inglaterra, por DISNEY et al. (1977), a escolha recaiu no ácido fórmico a $85 \%$ que previne o desenvolvimento de bactérias patogênicas como Salmonella e Clostridium botulinum e fungos.

KOMPIANG (1981), obteve silagem ácida com leve odor ácido utilizando $3 \% \mathrm{v} / \mathrm{p}$, da mistura de ácido fórmico e propiônico (1:1). 
Em trabalho realizado com sardinhas do Mediterrâneo (Sardina pilchardus), citado por TATTERSON \& WINDSOR (1974), indicou-se que a solução mais aceitável e de menor custo para a utilização de ácidos na preservação do material era a mistura na proporção de 6:1 de ácido sulfúrico/ácido fórmico.

Uma mistura de ácidos fórmico e propiônico tem sido recomendada, pois no caso de se utilizar a proporção de 1:1 de fórmico e propiônico e adição de $3 \%$ volume/peso à biomassa, a silagem que se obtém é estável, com aroma acidificado. Os ácidos minerais como o ácido hidroclorídrico e o ácido sulfúrico podem ser utilizados, pois são de baixo custo, porém tem a desvantagem de necessitar uma neutralização antes do consumo. Segundo Hanson \& Lovern², citados por TATTERSON \& WINDSOR (1974), o uso de ácido fórmico é menos corrosivo que ácidos minerais fortes e tem um excelente efeito bacteriostático.

TATTERSON \& WINDSOR (s.d.) indicam como adequada a utilização de ácido fórmico, a uma concentração de $85 \%$ e na proporção de $3,5 \%$ do peso total da biomassa.

A mistura de ácidos é mais recomendada do que a escolha de um único, devido ao fato de que alguns ácidos, como o ácido fórmico, permitem o crescimento de fungos, principalmente em silagens onde se utilizam fontes de carboidratos, além do pescado. $\mathrm{O}$ ácido propiônico inibe o crescimento de fungos a concentrações de $0,2 \%$ e a $\mathrm{pH}$ até 5,5 ; estes valores demonstram a clara atividade antifúngica do ácido propiônico e as vantagens do uso deste ácido orgânico no preparo de silagem. Em caso

${ }^{2}$ HANSON, S.W.F. \& LOVERN, J.A. Fishing News, '11, 1951. 
de silagem onde se adicionam fontes de carboidratos pela adição de glicose, o crescimento de Aspergillus flavus pode produzir aflatoxinas representando uma redução da aplicação da silagem especialmente em áreas tropicais (KOMPIANG, 1981).

Experimentos de laboratório indicam que a utilização de ácido mineral e ácido fórmico (que combinam baixo $\mathrm{pH}$ e ação bacteriostática), produz o tratamento ácido mais econômico (DISNEY et al., 1977).

\subsubsection{Monitoramento do processamento}

JAMES et al. (1977), realizaram um estudo comparativo de silagens preparadas por via fermentativa e por adição de ácido fórmico. Os resultados mostraram que a composição das silagens foi similar, embora a quantidade de aminoácidos livres tenha sido ligeiramente menor nos produtos fermentados. A hidrólise da proteína foi maior na digestão pelo ácido fórmico, comparada à produzida pelo ácido lático proveniente da fermentação. Ambas as silagens, apresentaram ausência de organismos patogênicos e não exigiram neutralização antes de serem oferecidas aos animais.

GILBERT \& RAA (1977), estudaram as propriedades do ácido propiônico e ácido fórmico, na preservação da silagem de vísceras de bacalhau (Gadus morhua), na proporção de 0,75 (v/p), utilizando os ácidos na mesma proporção (1:1). Concluiram que as silagens produzidas formam produtos estéreis a $\mathrm{pH} 4,3$, por vários meses, à temperatura ambiente em tanques abertos ou fechados. Consideraram que embora a silagem com ácidos fórmico e propiônico seja estéril, a quantidade de amônia 
aumenta, provavelmente por reações de desaminação catalizadas pelas enzimas endógenas do material utilizado.

SALES et al. (1992), elaboraram uma silagem de tilápia (Sarotherodon niloticus), com a adição de ácido fórmico a $3 \%$ (p/p) e acompanharam o processo de autólise à temperatura ambiente. Monitoraram pH, nitrogênio não protéico, nitrogênio $\alpha$-amínico durante 90 dias e a viscosidade durante os primeiros 30 dias, cabendo destacar os seguintes resultados: nitrogênio não protéico/nitrogênio total $=55-60 \%$ nos primeiros 5 dias de autólise; os valores de pH, foram ligeiramente superiores no início da autólise, com valor inicial de 4,10, mostrando-se praticamente inalterado até 90 dias, quando atingiu 3,82; a composição centesimal do autolisado foi: umidade $76,64 \%$; proteína bruta 14,90 ; lipídios totais $4,72 \%$ e cinza $3,74 \%$.

NUNES (1992), substituiu o ácido fórmico comumente utilizado no preparo da silagem por ácido acético, que segundo a autora, apresenta menor preço e maior disponibilidade, utilizando a proporção de 4:1 (v/p). A silagem produzida apresentou parâmetros similares aos encontrados por outros autores em silagem produzida com ácido fórmico. De acordo com a pesquisadora, esta silagem pode ser recomendada para a alimentação de suínos, aves e peixes.

\subsection{Silagem microbiana de pescado}

A fermentação microbiana ocorre no pescado, que é substrato rico em proteínas e lipídios, desde que haja uma fonte de carboidratos adicionada à biomassa. 
Assim, as bactérias produtoras de ácido lático propiciarão a preservação ácida à silagem (OETTERER, 1994).

O pescado ensilado na moderna prática utilizada tanto na Europa como na América, consta de uma mistura de pescado com carboidratos, como as farinhas de cereais, de arroz e de milho, a mandioca ou o melaço colocados em contacto com culturas inóculo de Lactobacillus plantarum, Pediococcus, Streptococcus lactis, Saccharomyces platensis e outros microrganismos (OETTERER, 1994).

\subsubsection{Cultura inóculo}

A silagem de pescado, na prática, não poderá ser feita assepticamente, por isso a fermentação será dependente do balanço da população microbiana. Como no pescado ocorre um pequeno número de bactérias produtoras de ácido lático, deve-se adicionar estes microrganismos, que serão o "starter" da fermentação (OETTERER, 1993/94).

O número inicial de bactérias produtoras do ácido lático deverá estar próximo de $2 \times 10^{8}$ por grama (OETTERER, 1993/94).

As bactérias produtoras de ácido lático homofermentativas crescem nos substratos que são os carboidratos e reduzem o pH para 4,5-4,0 em 48 a 50 horas. Essas formas homofermentativas produzem 2 moles de ácido lático por mol de glicose adicionada. As heterofermentativas produzem, além do ácido lático, o álcool élico e o dióxido de carbono, e também outras substâncias, como as que conferem sabor amargo 
ao produto, a partir de frutose adicionada (OETTERER, 1993/94).

A inoculação do microrganismo deve ser feita com pelo menos $10^{7}$ bactérias/grama de cereal. Durante os primeiros estágios da fermentação o nível de microrganismos gram-negativos se reduz. As cepas devem crescer em meio apropriado, cerca de 48 horas antes do uso, assim chega-se ao número de células suficientes e na fase apropriada de crescimento para serem inoculadas na biomassa (ANDRADE, 1983; OTTATI, 1990).

Como inóculo, utiliza-se no Japão, produtos de fermentação de arroz por Aspergillus oryzae. Os fungos contribuem com proteínas e outras enzimas produtoras de "flavour" e textura desejáveis (ANDRADE, 1983).

Na Austrália, ensila-se resíduos de pescado com cevada maltada e cereais em grão, prevalescendo o efeito das enzimas do malte que elevam o teor de ácido lático (ANDRADE, 1983).

Cereais pré-fermentados com Pediococcus acidillactici e Lactobacillus plantarum promovem uma silagem em cerca de 30 horas, chegando o $\mathrm{pH}$ a 4,5 (LINDGREN \& PLEJE, 1983).

Produtos comerciais para fermentação controlada de silagem contendo Lactobacillus plantarum e Pediococcus pentasacens já são empregados em silagem vegetal (FERMENTAÇÃO controlada de silagem é testada no Brasil, 1989).

A dificuldade de introdução da silagem biológica a nível rural se deve à falta de cultura "starter". Entretanto, os resíduos de pescado podem ser ensilados com sucesso utilizando, por exemplo, o melaço, sem o inóculo, mas mantendo a proporção 
peixe:melaço de pelo menos 10:1 (KOMPIANG, 1981).

Uma vez que uma boa silagem biológica seja preparada, poderá ser utilizada como um inóculo para produção subsequente. Recomenda-se a seguinte combinação: 100 partes de peixe picado, 20 partes de melaço e 10 partes de silagem "madura" (KOMPIANG, 1981).

Estudos atuais pretendem aproveitar mais efetivamente a habilidade de certas culturas microbianas para secretar proteases que solubilizem biomassas aquáticas. Assim, espécies como Bacillus megaterium, Aeromonas hidrophila e Pseudomonas mariniglutinosa podem produzir um significativo teor de proteases se fixadas em uma suspensão de biomassa de pescado (VENUGOPAL et al., 1989).

O rendimento de produção de silagem aumenta em $30 \%$ ao aproveitar-se continuamente a produção da enzima microbiana. O processo de imobilização de células microbianas dentro do sistema pode ser feito com o uso de reatores onde as células são fixadas em alginato de cálcio. Os nutrientes solúveis da carne permitem que os microrganismos cresçam e liberem continuamente as enzimas no sistema (VENUGOPAL et al., 1989).

HASSAN \& HEATH (1986) fermentaram peixes inteiros, vísceras e cabeças com Lactobacillus plantarum e constataram que um mínimo de $5 \%$ de lactose é necessário para que a fermentação ocorra. O pré-aquecimento do peixe resulta em uma redução do teor de nitrogênio presente antes e depois da fermentação. As relações entre o crescimento de bactérias ácido-láticas, leveduras e fungos e o pH indicam que, em operações de larga escala, é necessário adicionar um agente antifúngico para alcançar e 
manter o pH suficientemente baixo para a fermentação e estocagem da silagem. A temperatura de 25 a $35^{\circ} \mathrm{C}$ e uma "cultura starter" de $10^{3}$ células/g peixe produzem uma boa fermentação.

Segundo HERON et al. (1993) em silagem inoculadas com $L$. plantanum e $P$. acidilactici há diminuição rápida do $\mathrm{pH}$ e alto teor de carboidratos solúveis em água, mostrando dessa forma que estes microrganismos são eficientes no uso dos açúcares disponíveis.

Os lactobacilus são comumente usados como meios de preservação na fermentação de gêneros alimenticios e alimentos por serem bons produtores de ácido lático; seu uso tem sido muito difundido na preservação carnes, vegetais e silagens (AUKRUST \& BLOM, 1992; HERIBAN et al., 1993).

Segundo STANTON \& YEOH (1977), para que a silagem biologica seja um sucesso, é recomendável a predominância de "strains" homofermentativos; com relação ao teor de carboidratos utilizados, estes podem variar entre 10 e $50 \%$ do peso total do peixe.

Os "strains" de pediococus possuem a habilidade única de produzir ácido lático mais rapidamente a temperaturas entre $24-43^{\circ} \mathrm{C}$ (KARMAS \& LAUBER, 1987).

No processamento de surimi fermentado com bactérias ácido-láticas, estas talvéz sejam as responsáveis pela eliminação do sabor a peixe; o que se espera que aconteça com a silagem.

Os produtos fermentados com lactobacilus e leveduras favorecem significativamente o aumento da digestibilidade das proteínas, já que a microflora pode 
produzir enzimas proteolíticas durante a fermentação. (KHETARPAUL \& CHAUHAN, 1990)

\subsubsection{Fonte de carboidratos}

Com adição de melaço no início do processo, há elevação do pH da mistura de peixes, que conforme a temperatura do processo atrasa o desenvolvimento bacteriano inicial. A adição de ácido clorídrico com a finalidade de abaixar o pH pode inibir o crescimento bacteriano. A redução do $\mathrm{pH}$ pode ocorrer mais rapidamente e com a utilização de menos carboidratos a temperaturas de 25 a $30^{\circ} \mathrm{C}$; portanto em regiões mais frias a silagem precisará de calor adicional (KOMPIANG, 1981; ANDRADE, 1983; SHOEMAKER, 1986; LUNA et al. 1990; OTTATI et al. 1990).

Silagens empregando bactérias e fungos e substratos adicionados como açúcar, lactose ou glicose, devem receber ácidos clorídrico e/ou fórmico ou ainda devem ser preservadas com adição de ácido sórbico. A rancidez da gordura pode ser evitada adicionando-se 150 ppm de etoxiquinina no início do processo (OETTERER, 1993/94).

A combinação de pescado e palha de trigo, misturadas e ensiladas juntas, produziu uma boa fermentação pois houve produção adequada de ácido lático (CHIRASE et al., 1985).

Nas silagens biológicas nas quais se utilizam $L$. plantarum como "cultura starter" e melaço como fonte de carboidratos, a redução do $\mathrm{pH}$ foi mais rápida do que quando foi utilizado soro de leite (WYK \& HEYDENRYCH, 1985). 
Em silagens biológicas, as bactérias produtoras de ácido lático fermentam os açúcares presentes tranformando-os em ácidos orgânicos, assim ocorre uma diminuição do $\mathrm{pH}$, o qual inibe o crescimento de microrganismos putrefativos e patogênicos incluindo o Clostridium botulinum, previnindo ainda a rancificação (STANTON \& YEOH, 1977; ARECHE \& BERENZ, 1987).

A adição de mistura de malte e cereais; melaço e cereais; malte e tapioca e melaço e tapioca podem também ser usados para fermentar pescado.

Segundo KOMPIANG (1981) os carboidratos adicionados ao pescado podem atuar como uma fonte natural de lactobacilus.

Em estudos conduzidos utilizando melaço como fonte de carboidratos a silagem produrida foi adequada já que apresentam aroma agradavél, ao contrário da silagem química que apresentou aroma pungente (JAMES et al., 1977).

\subsubsection{Processo fermentativo}

O processo consiste em se misturar pescado moído com os cereais, ou o melaço, ou ambos, e o fermento (inóculo). Aditivos podem ser utilizados como antífúngicos, como é o caso do ácido sórbico e do ácido propiônico (OTTATI et al., 1990).

A fermentação microbiana altera a composição em proteína e cinza e provoca decréscimo no teor de lipídios, no índice de peróxidos e no índice de ácido tiobarbitúrico, aumentando as bases nitrogenadas voláteis e os ácidos graxos com 
configuração ômega-3 (YONE et al. 1986; HOSSAIN et al. 1987).

A volatilização dos componentes nitrogenados aumenta $\mathrm{opH}$ e força $\mathrm{o}$ microrganismo a produzir mais ácido. A produção das substâncias básicas é dependente da temperatura e não pode ser atribuída apenas à atividade microbiana (LINDGREN \& PLEJE, 1983).

A atividade proteolítica ocorre principalmente por ação da catepsina e das proteases presentes no tecido muscular e, em menor grau, por proteases do tecido intestinal. (LINDGREN \& PLEJE, 1983).

A silagem de pescado ou "tepsil" pode ser produzida manualmente em pequena escala pela mistura do peixe picado com ácido em tambores ou por fermentação com melaço em sacos plásticos ou ainda em processamento totalmente automatizado, em escala industrial (KOMPIANG, 1990).

O processo de conversão dos carboidratos para ácido lático é anaeróbico e pode ser dividido em três fases. Inicialmente o amido presente é hidrolizado para malte através das enzimas alfa e beta amilases as moléculas de malte são hidrolizadas a glicose, pela enzima maltase e a última etapa é a conversão de glicose a ácido lático; outras substâncias como ácido acético e etanol são também formadas (STANTON \& YEOH, 1977).

$\mathrm{O}$ pH baixo, o teor de ácido lático formado, a presença de pequenas quantidades de outros ácidos orgânicos e a presença de algumas substâncias inibidoras asseguram um habitat desfavorável para os microrganismos patogênicos, favorecendo por sua vez a ação de bactérias ácido-láticas utilizadas para a preservação das silagens 
(INTERNATIONALCOMISSION ON MICROBIOLOGIALESPECIFICATIONS FOR FOODS, 1980).

A biopreservação pelo ácido lático acredita-se que ocorra devido à produção de ácido e possivelmente pela habilidade de certas bactérias ácido-láticas em produzir compostos antibacterianos chamados bacteriocinas (BORRESEN, 1990).

\subsubsection{Monitoramento do processo}

HASSAN \& HEATH (1987) compararam silagens de pescado antes e depois da fermentação com Lactobacillus plantarum. A silagem de truta apresenta uma alta porcentagem de proteína e de lipídios e menor teor de cinza do que a silagem preparada com "white perch". Os aminoácidos totais aumentam como conseqüência da fermentação. Depois da silagem ser armazenada a temperatura ambiente ou a $37^{\circ} \mathrm{C}$ por 35 dias houve uma diminuição no teor de umidade e um aumento no teor de lipídios. A diminuição no teor de umidade foi devido à condensação e à extração do ácido lático resultando em aumento dos teores de lipídios. Durante o armazenamento todos os aminoácidos foram incrementados em menor escala, o que foi atribuido à diminuição da umidade. Quanto ao pH, não houve alteração durante o armazenamento, mas a silagem armazenada à temperatura ambiente mostrou-se mais ácida, uma vez que à temperatura ambiente consegue-se um pH suficientemente baixo, que permite uma boa fermentação. À temperatura ambiente ocorre um aumento do nitrogênio solúvel em água que aumenta com o tempo de armazenamento. Estas alterações indicam melhoria na digestibilidade 
da silagem. Amostras armazenadas a $37^{\circ} \mathrm{C}$ apresentam maior teor de bases voláteis que as armazenadas a temperatura ambiente e estas aumentam, com o período de armazenamento.

Em estudos comparativos feitos por $\mathrm{James}^{3}$ et al. 1975, citados por ARECHE \& BERENZ (1987) em silagem biológica produzida por L. plantarum e silagem com ácido fórmico, verificou-se que ambas são bastante estáveis; a composição química foi similar, com poucas variações no teor de nitrogênio após a adição de carboidratos nas silagens biológicas. Organolepticamente, a silagem com ácido fórmico apresenta um ligeiro aroma ácido, já a biológica apresenta um aroma agradável.

Segundo REYES et al. (1991), a flora ácido lática não se desenvolve bem a temperaturas superiores a $55^{\circ} \mathrm{C}$; a flora microbiana do pescado e/ou resíduos de frutas não são suficientes para elaborar silagens estáveis, pelo que torna-se imprescindível a adição de melaço e inóculo para que ocorra a efetiva diminuição do pH e obter um produto estável. A adição do melaço contribui com os carboidratos necessários a uma fermentação mais rápida, além de contribuir com sua flora bacteriana, a qual incrementa a eficiência do processo de diminuição do $\mathrm{pH}$, que por sua vez auxilia na preservação do produto.

${ }^{3}$ JAMES, M.A.I \& NAIR, M.R. Comparative study of fish ensilage prepared by microbial fermentation and formic acid ensilage. Central Institute of Fisheries Technology. India. p. 273-5, 1975. 


\subsubsection{O produto final}

A silagem biológica de pescado é o produto final da fermentação controlada em processos nos quais são adicionados aos resíduos de pescado uma fonte de carboidratos, os quais são fermentados por bactérias ácido láticas. A produção de ácido lático diminui o pH para valores abaixo de 4,0; esta redução inibe o crescimento de bactérias como Staphylococcus, Escherichia coli, Serratia, Enterobacter, Citrobacter, Achromobacter e Pseudomonas (WYK \& HEYDENRYCH, 1985).

A elaboração de silagem biológica em condições ambientais mostra-se satisfatória quando o peixe é misturado com $15 \%$ de melaço, $1 \%$ de inóculo de $L$. plantarum e $0,25 \%$ de ácido sórbico, obtendo-se um produto de excelente qualidade física, química e microbiológica (OTTATI et al, 1990)

Estudos realizados por ARECHE \& BERENZ (1987) utilizando Lactobacillus bulgaricus e Streptrococcus thermophylus mostravam que estas culturas são capazes de produzir grandes alterações no pH e na acidez nos resíduos cozidos de pescado; quando se utiliza como substrato o açúcar de cana, a quantidade da cultura starter para que o processo de fermentação possa se desenvolver deve ser entre 5-10\%, não sendo necessário adicionar sal; a fermentação pode acontecer em condições de anaerobiose e é do tipo homo-heterofermentativa; a diminuição do $\mathrm{pH}$ de 6,1 para 4,0 nas primeiras 48 horas é de suma importância para manter a silagem estável por longos períodos. 
JOHNSON et al. (1985) ensilaram resíduos de pescado acidificados com ácido fórmico ou fermentados com "cultura starter" e melaço; o produto resultante foi misturado com farelo de trigo na proporção de $85: 15$ e seco a $70^{\circ} \mathrm{C}$. A composição centesimal do produto final foi de $32,5 \%$ de proteína para a silagem biológica e $37,1 \%$ para a silagem química; a silagem biológica apresentou menos aminoácidos que a silagem química. A conversão de proteína bruta em aminoácidos foi de somente $78,7 \%$; acredita-se, que este fato ocorra devido à formação de produtos da reação de "Maillard" durante a secagem. Quando testados em frangos de engorda, tanto a silagem química quanto a biológica não apresentaram diferenças significativas quando comparadas ao grupo padrão que continha soja.

Em estudos realizados por JAMES et al. (1977) o nitrogênio protéico encontrado nas silagens biológicas oscilou entre $1,7 \%$ a $2,14 \%$; entretanto nas silagens químicas os valores foram de $2,24 \%$ a $2,25 \%$. O baixo teor de nitrogênio encontrado nas silagens biológicas foi devido à adição de carboidratos e a pouca diluição; com relação ao nitrogênio solúvel foi também encontrada tendência similar; já para o nitrogênio não protéico o alfa amínico, os valores foram levemente superiores (JAMES et al., 1977).

Durante o armazenamento da silagem biológica foram observados mudanças na composição de aminoácidos livres, e em estágios posteriores ocorrem perdas de aminoácidos, os quais são atribuídos a interações destes com os açúcares do melaço não utilizados (JAMES et al., 1977). 
A silagem biológica tem sido usada como ração para camundongos experimentais, gatos e suinos e seu valor nutricional é comparável com o da farinha de peixe (JAMES et al., 1977). 


\section{MATERIAL E MÉTODOS}

\subsection{Matéria prima}

\subsubsection{Preparação da massa homogênea}

A matéria prima constituiu-se de sardinhas (Sardinella brasiliensis) na forma congelada acondicionada em sacos plásticos, provenientes do mercado atacadista de Piracicaba e assim transportadas ao Laboratório de Pescado do Departamento de Ciência e Tecnologia Agroindustrial, da Escola Superior de Agricultura "Luiz de Queiroz", da Universidade de São Paulo, em Piracicaba.

Procedeu-se a evisceração, descabeçamento e eliminação da cauda. A seguir, o material foi picado manualmente constituindo-se de porções íntegras e heterogêneas permanecendo nestas, as escamas, nadadeiras e partes da coluna vertebral. A seguir, o material foi moído em equipamento elétrico Hobart, modêlo " $\mathrm{H}$ ", de aço inoxidável e apresentou-se como uma massa homogênea.

Este procedimento foi feito afim de simular o material residual comestŕvel comumente descartado na indústria. A coleta direta na indústria não foi feita porque o transporte até o laboratório exigiria um meio adicional de conservação dos 
resíduos e assim descaracterizaria a matéria prima. Além disso, o resíduo industrial se constitui em matéria bruta, sem triagem da parte comestível.

\subsection{Culturas inóculo}

Foram utilizados como cultura inóculo linhagens de Lactobacillus plantarum FT-074-B e Pediococcus acidilactici FT-025-B, ambas linhagens capazes de produzir ácido lático a partir da degradação de um substrato, as quais foram obtidas do Laboratório de Laticínios do Departamento de Tecnologia Agroindustrial da Escola Superior de Agricultura "Luiz de Queiróz" da Universidade de São Paulo.

\subsubsection{Meio de cultura}

A partir de dois tubos de ensaio com meio de crescimento e as culturas previamente ativadas, procedeu-se a multiplicação das mesmas, utilizando meio de crescimento para Streptococcus e Lactobacillus (Leuconostoc) e cuja composição é a seguinte: 
Extrato de levedura $20,0 \mathrm{~g}$

Peptona

$5,0 \mathrm{~g}$

Dextrose

$10,0 \mathrm{~g}$

$\mathrm{KH}_{2} \mathrm{PO}_{4}$

$2,0 \mathrm{~g}$

Ágar*

$18,0 \mathrm{~g}$

$\mathrm{H}_{2} \mathrm{O}$ destilada $1000 \mathrm{ml}$

" para plaqueamento

\subsubsection{Solução para resuspender as células}

Para resuspensão das células centrifugadas foi utilizada solução salina $0,85 \%$.

\subsubsection{Multiplicação das culturas}

O meio preparado foi autoclavado a $121^{\circ} \mathrm{C}, 1 \mathrm{~atm}$ por 20 minutos e distribuído em tubos de ensaio, e erlenmeyers, nas quantidades de $5 \mathrm{ml}, 100 \mathrm{ml}$ e $500 \mathrm{ml}$.

Procedeu-se à multiplicação das culturas partindo-se de uma alíquota de $0,1 \mathrm{ml}$ da cultura previamente ativada, inoculada no tubo de ensaio contendo $5 \mathrm{ml}$ do meio, o qual foi incubado a $35^{\circ} \mathrm{C}$ por 24 horas. 
Após 24 horas tomaram-se alíquotas de 1 e $5 \mathrm{ml}$ dos tubos de ensaio e inocularam-se nos erlenmeyers contendo 100 e $500 \mathrm{ml}$, respectivamente, de meio e incubados a $35^{\circ} \mathrm{C}$ por 48 horas, para dessa forma atingirem-se concentrações de pelo menos $10^{8}$ células $/ \mathrm{ml}$.

\subsubsection{Concentração de células}

Para se determinar a concentração de células/ml procedeu-se a contagem em placas através de diluições em série.

\subsubsection{Obtenção da solução inóculo}

O material contendo os microrganismos foram centrifugados em centrífuga modelo PR-2 série $8044 \mathrm{H} \mathrm{a} 25^{\circ} \mathrm{C}$. O tempo necessário para a separação da massa de células foi de 15 minutos a $280 \mathrm{~g}$ para o $\mathrm{L}$. plantarum e de 30 minutos para $\mathrm{o}$ P. acidilactici.

As massas centrifugadas foram suspensas, em solução salina a $0,85 \%$ até completar $40 \mathrm{ml}$. Em cada $500 \mathrm{~g}$ de silagem, foram inoculados $7 \mathrm{ml}$ da solução com as células suspensas (solução inóculo).

Utilizou-se para as outras silagens de $500 \mathrm{~g}$ cada, os meios de cultura contendo a concentração celular necessária conforme descrito em 3.2.2. (meio inóculo). 


\subsection{Melaço}

O melaço foi obtido no Setor de Açúcar e Álcool do Departamento de Ciência e Tecnologia Agroindustrial da ESALQ/USP. O melaço utilizado tem como composição $24 \%$ de umidade, $60 \%$ de carboidratos totais e $8,5 \%$ de cinza.

\subsection{Métodos}

\subsubsection{Preparo da silagem química}

A massa homogênea preparada como em 3.3.1. foi dividida em lotes e colocada em 30 bequeres de $2.000 \mathrm{ml}$ cada um. Cada bequer recebeu $500 \mathrm{~g}$ de massa homogênea e uma mistura de ácido fórmico a $88 \%$ e propiônico a $100 \%$ na proporção de $1: 1$.

Utilizou-se a mistura de ácidos a $3 \%$ (v/p) em relação à biomassa (KOMPIANG, 1981). Portanto, cada bequer, recebeu 15,95 $\mathrm{ml}$ da mistura de ácidos.

A massa foi revolvida manualmente com espátula para a acidificação se tornar homogênea.

A silagem química se constituiu em um pré-tratamento para o preparo da silagem microbiológica. 


\subsubsection{Preparo da silagem microbiológica}

A silagem microbiológica foi preparada a partir da silagem química, decorridos 20 dias do tempo inicial, quando o pH da mistura já se havia estabilizado.

Foram utilizados 30 beckers de $2000 \mathrm{ml}$ cada um, sendo divididos em 6 lotes de 5 .

Para o processo de fermentação foram estabelecidas três condições diferentes para cada microrganismo, a saber:

Tratamento I

- 500 g silagem química

- 7 ml de solução inóculo de L. plantarum

- $100 \mathrm{ml}$ melaço

- $100 \mathrm{ml} \mathrm{H}_{2} \mathrm{O}$ destilada

\section{Tratamento II}

- $500 \mathrm{~g}$ de silagem química

- $7 \mathrm{ml}$ de solução inóculo de $P$. acidilactici

- $100 \mathrm{ml}$ melaço

- $100 \mathrm{ml} \mathrm{H}_{2} \mathrm{O}$ destilada. 
Tratamento III

- 500 g de silagem química

- $100 \mathrm{ml}$ de meio inóculo de $L$. plantarum

- $100 \mathrm{ml}$ melaço

\section{Tratamento IV}

- 500 g de silagem química

- $100 \mathrm{ml}$ de meio inóculo de $P$. acidilactici

- $100 \mathrm{ml}$ melaço

\section{Tratamento V}

- 500 g de silagem química

- $100 \mathrm{ml}$ de meio inóculo de $L$. plantarum

- $100 \mathrm{ml} \mathrm{H}_{2} \mathrm{O}$ destilada

\section{Tratamento VI}

- 500 g de silagem química

- $100 \mathrm{ml}$ de meio inóculo de $P$. acidilactici

- $100 \mathrm{ml} \mathrm{H}_{2} \mathrm{O}$ destilada 


\subsubsection{Avaliação Sensorial}

Após a preparação das silagens foi feito um acompanhamento por observação sensorial visando cor, aroma, textura (consistência).

3.4.4. Coleta de amostras das silagens para análise

Os sistemas foram revolvidos antes de cada coleta.

O tempo inicial considerado foi de 48 horas após a inoculação da cultura. Os demais foram analisados semanalmente.

\subsubsection{Análises químicas}

\subsubsection{Determinação do pH}

$\mathrm{O} \mathrm{pH}$ foi determinado em pHmetro digital, que proporciona leitura de duas casas decimais, sempre precedido de revolvimento da massa, conforme descrito em 3.4.2.

Para uma melhor homogeneização as silagens foram revolvidas com bastão de vidro, foi feita a medição do $\mathrm{pH}$ da silagem química, uma segunda medição foi feita logo após a adição do melaço, e uma terceira logo após a inoculação das culturas e a última ao final do experimento. 


\subsubsection{Composição centesimal}

As análises químicas para umidade, proteína bruta, lipŕdios e cinza foram realizadas no material seco de acordo com a metodologia indicada pela AOAC (1975) em triplicata, na matéria-prima e em cada uma das amostras coletadas.

O teor de nitrogênio total foi determinado pelo método Microkjeldhal, sendo o teor protéico determinado multiplicando-se o conteúdo de nitrogênio total pelo fator 6,25 .

Os lipídios foram determinados utilizando-se o extrator de Soxhlet. Na extração, utilizou-se como solvente o éter de petróleo, à temperatura de $40-50^{\circ} \mathrm{C}$, em refluxo contínuo da amostra por 8 horas. Recuperado o solvente, os balões foram retirados e colocados em estufa por 20 minutos a $100^{\circ} \mathrm{C}$, deixando esfriar em dessecador e pesados, obtendo-se a massa de extrato etéreo por diferença do peso do balão.

A cinza foi obtida incinerando a amostra em mufla à temperatura de $600^{\circ} \mathrm{C}$ por 2 horas.

Os carboidratos foram determinados por diferença entre a somatória dos demais componentes, considerando o total 100.

\subsubsection{Determinação de nitrogênio não protéico}

O nitrogênio não protéico foi determinado segundo o método citado por MEZINCESCU \& SZABO (1936), utilizando o ácido tricloroacético para precipitar o 
nitrogênio proveniente da proteína.

\subsubsection{Determinação de nitrogênio protéico}

O nitrogênio protéico foi determinado subtraindo-se do nitrogênio total, o nitrogênio não protéico.

\subsubsection{Digestibilidade "in vitro"}

A digestibilidade "in vitro" foi determinada segundo metodologia descrita por AKESON \& STAHMAN (1964), a qual se baseia na hidrólise enzimática das proteínas com pepsina e pancreatina, seguida da determinação do nitrogênio não precipitável com ácido pícrico. A amostra foi misturada com solução de pepsina em $\mathrm{HCl}$ $01 \mathrm{~N}$ na concentração de $3 \mathrm{mg} / \mathrm{ml}$ e deixada a $37^{\circ} \mathrm{C}$ por 3 horas. Posteriormente, foi neutralizada com $\mathrm{NaOH} 0,1 \mathrm{~N}$ e adicionada solução de pancreatina em tampão fosfato $0,1 \mathrm{M}$ à $\mathrm{pH} 8,0$ na concentração de $\mathbf{0 , 4 \%}$ sendo incubada a mistura por 24 horas sob agitação a $37^{\circ} \mathrm{C}$. Posteriormente centrifugou-se a 11.000 x g por 15 minutos, acrescentando-se, para cada parte do sobrenadante, 5 partes de ácido pícrico, sendo determinado o nitrogênio através de Microkjeldahl, como descrito anteriormente. 


\subsubsection{Análise de ácidos graxos}

Para a análise da composição em ácidos graxos a amostra constitui-se do óleo extraído previamente em extrator de Soxhlet, utilizando-se como solvente o éter de petróleo.

Os ácidos graxos foram determinados segundo a técnica de HARTMAN \& LAGO (1973), utilizando cromatógrafo a gás com as seguintes especificações:

- Coluna cromatográfica de sîlica fundida FI-547 de 12 m e 0,25mm d.i. (Carbonax 20m).

- Programação de temperatura: $150^{\circ} \mathrm{C}$ por 5 minutos e aquecimento de $150^{\circ} \mathrm{C}$ a $210^{\circ} \mathrm{C}$ a uma velocidade de $3^{\circ} \mathrm{C} /$ minuto, permanecendo a $210^{\circ} \mathrm{C}$ por 10 minutos.

- Temperatura do vaporizador: $230^{\circ} \mathrm{C}$.

- Temperatura do detector: $250^{\circ} \mathrm{C}$.

- Gás de arraste: $\mathrm{H}_{2}$.

- Fluxo de gases para o detector de ionização de chama: $H_{2}=40$ $\mathrm{ml} / \mathrm{min} . ; \mathrm{N}_{2}=40 \mathrm{ml} / \mathrm{min} . ;$ ar comprimido $=300 \mathrm{ml} / \mathrm{min}$.

- Razão de divisão da amostra no injetor $=1 / 100$

- Integrador utilizado C.G. 300.

- Padrão utilizado: estermdtílico do ácido 1-decanóico.

A identificação e quantificação dos ácidos graxos foi obtida por comparação do tempo de retenção e área de pico dos ácidos graxos desconhecidos com 
o do padrão utilizado.

\subsection{Preparo das farinhas e das dietas}

As amostras das silagens foram evaporadas em estufa com circulação forçada a $55^{\circ} \mathrm{C}$ até peso constante. Os materiais secos foram triturados em moinho de facas para obtenção das farinhas, seguindo para determinação de proteína na matéria seca, utilizando metodologia descrita em AOAC (1990) (Tabela 1), em seguida formularam-se as dietas, empregando-se o método estabelecido pela AOAC (1990), com $10 \%$ de proteína, $4 \%$ da mistura salina, $1 \%$ da mistura vitamínica, $8 \%$ de óleo de milho na dieta de caseína; nas dietas com silagem trabalhou-se com o teor de gordura existente na silagem e posteriormente completaram-se as dietas com amido de milho até $100 \%$.

\subsection{Ensaio Biológico}

Foram utilizados no presente trabalho Rattus norvegicus variedade albinus, linhagem wistar, machos obtidos de cruzamentos sucessivos no biotério do setor de Nutrição Humana e Alimentos da Escola Superior de Agricultura "Luiz de Queiróz" da Universidade de São Paulo. Os animais tinham 21-23 dias de idade com uma variação de peso não mais do que $5 \%$ dentro e entre os grupos. Cada tratamento foi constituído por 6 animais os quais receberam um tratamento específico como detalhado a seguir: 
Dieta I = Silagem meio inóculo de $L$. plantarum + silagem meio inóculo de P. acidilactici.

Dieta II $=$ Silagem meio inóculo de $L$. plantarum + silagem meio inóculo de P. acidilactici + melaço.

Dieta III = Silagem solução inóculo de $L$. plantarum + silagem solução inóculo de $P$. acidilactici + melaço.

Dieta IV $=$ Caseina (Padrão).

Dieta V = Aprotéica.

Tabela 1. Composição química das dietas experimentais para o ensaio biológico.

\begin{tabular}{lcccccc}
\hline $\begin{array}{l}\text { Dietas } \\
\text { Experimentais }\end{array}$ & $\begin{array}{c}\text { Matéria } \\
\text { seca } \\
\mathrm{g} / 100 \mathrm{~g}\end{array}$ & $\begin{array}{c}\text { Umidade } \\
\mathrm{g} / 100 \mathrm{~g}\end{array}$ & $\begin{array}{r}\text { Proteína } \\
\mathrm{g} / 100 \mathrm{~g}\end{array}$ & $\begin{array}{r}\text { Extrato } \\
\text { étereo } \\
\mathrm{g} / 100 \mathrm{~g}\end{array}$ & $\begin{array}{r}\text { Cinza } \\
\mathrm{g} / 100 \mathrm{~g}\end{array}$ & $\begin{array}{r}\text { Fibra } \\
\text { bruta } \\
\mathrm{g} / 100 \mathrm{~g}\end{array}$ \\
\hline Dieta I & 90,4 & 9,6 & 10,2 & 8,2 & 5,2 & 0,11 \\
Dieta II & 89,9 & 10,1 & 10,1 & 7,9 & 4,4 & 0,14 \\
Dieta II I & 89,9 & 10,1 & 9,9 & 8,1 & 4,5 & 0,18 \\
Dieta IV & 90,1 & 9,9 & 10,0 & 8,1 & 3,4 & - \\
\hline
\end{tabular}

Os animais permaneceram em gaiolas individuais, receberam água e alimentos "ad libitum", sendo o peso e o consumo dos alimentos registrados três vezes por semana durante os 28 dias de duração do experimento. As fezes excretadas pelos ratos foram também coletadas três vezes por semana, secas em estufa a $105^{\circ} \mathrm{C}$ até peso constante, pesadas e moídas. Uma amostra das fezes de cada animal foi retirada para análise do teor de nitrogênio, a fim de se calcular a digestibilidade. No vigésimo oitavo 
dia do experimento, após jejum de 12 horas, todos os animais foram sacrificados. As cavidades abdominais, toráxicas e cefálicas foram abertas e os animais foram secados em estufa a $105^{\circ} \mathrm{C}$, até peso constante. $\mathrm{O}$ material seco foi moído e retiradas amostras para detrerminação do nitrogênio da carcaça para cálculo do NPU (Net Protein Utilization).

O nitrogênio das fezes e das carcaças foi determinado pela técnica descrita pelo AOAC (1990).

Incluiu-se uma dieta aprotéica, para fins de cálculo de digestibilidade e NPU (Net Protein Utilization).

Os cálculos foram feitos da seguinte forma:

Digestibilidade \% (D \%):
Proteína - Proteína - Proteína excretada pelo consumida excretada grupo aprotéico
$\mathrm{D} \%=\frac{(24 \text { horas }) \quad(24 \text { horas }) \quad(24 \text { horas })}{\text { Proteína consumida em } 24 \text { horas. }}$

Utilização Protéica Líquida (NPU) (MILLER \& BENDER, 1955):

$$
\mathrm{NPU}=\frac{[\mathrm{Bf}-(\mathrm{Bk}+\mathrm{Ik})]}{\text { If }}
$$

onde: $\mathrm{Bf}=$ nitrogênio da carcaça do grupo experimental

If $=$ nitrogênio ingerido

$\mathrm{Bk}=$ nitrogênio da carcaça do grupo aprotéico

IK = nitrogênio ingerido pelo grupo aprotéico 
Valor Biológico (V.B):

$$
\text { V.B }=\frac{\text { NPU }}{D}
$$

Razão de Eficiência Protéica (PER) (OSBORNE et al., 1919):

$$
\text { PER }=\frac{\text { ganho peso em gramas }}{\text { proteína ingerida em gramas }}
$$

Coeficiente de Eficiência Alimentar (CEA):

$$
\mathrm{CEA}=\frac{\text { ganho de peso em gramas }}{\text { consumo da ração em gramas }}
$$

\subsection{Análise estatística}

Para a análise dos dados obtidos do ensaio biológico aplicou-se a técnica de análise de variância, com a utilização do teste Tukey (5\%) referente ao delineamento inteiramente casualizado adotado, com 6 repetições (GOMES, 1982). 


\section{RESULTADOS E DISCUSSÃO}

4.1. Fluxograma para produção de silagens microbiológicas de pescado

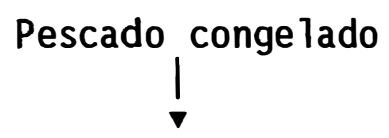

DESCONGELAMENTO (ambiente)

CORTE MANUAL

(descabeçamento, evisceração e el iminação da cauda)

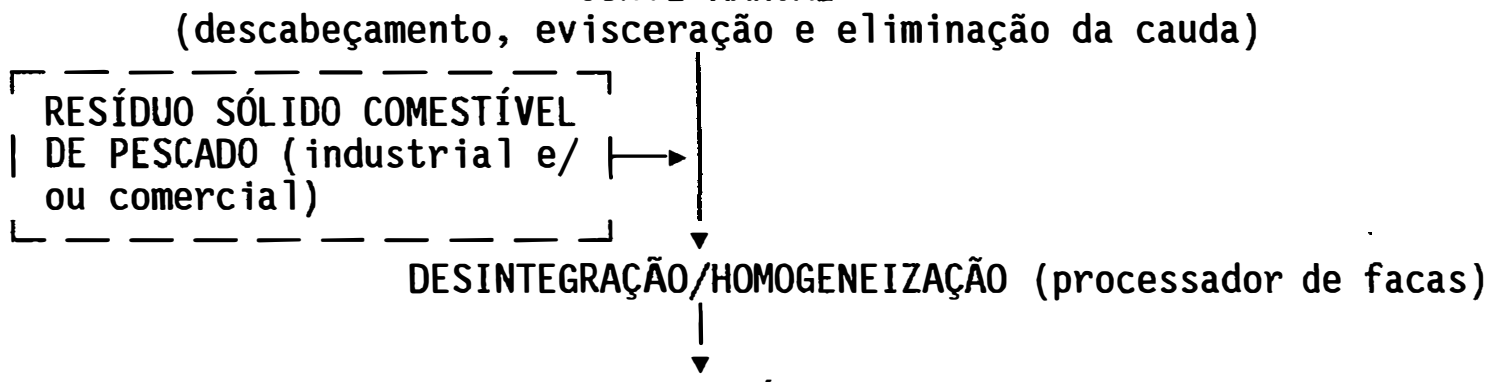

TRATAMENTO QUÍMICO

(adição de ácido fórmico e propiônico $1: 1$ na proporção de $3 \% \mathrm{v} / \mathrm{p}$ em relação a massa de pescado, à temperatura ambiente média de $26^{\circ} \mathrm{C}$ )

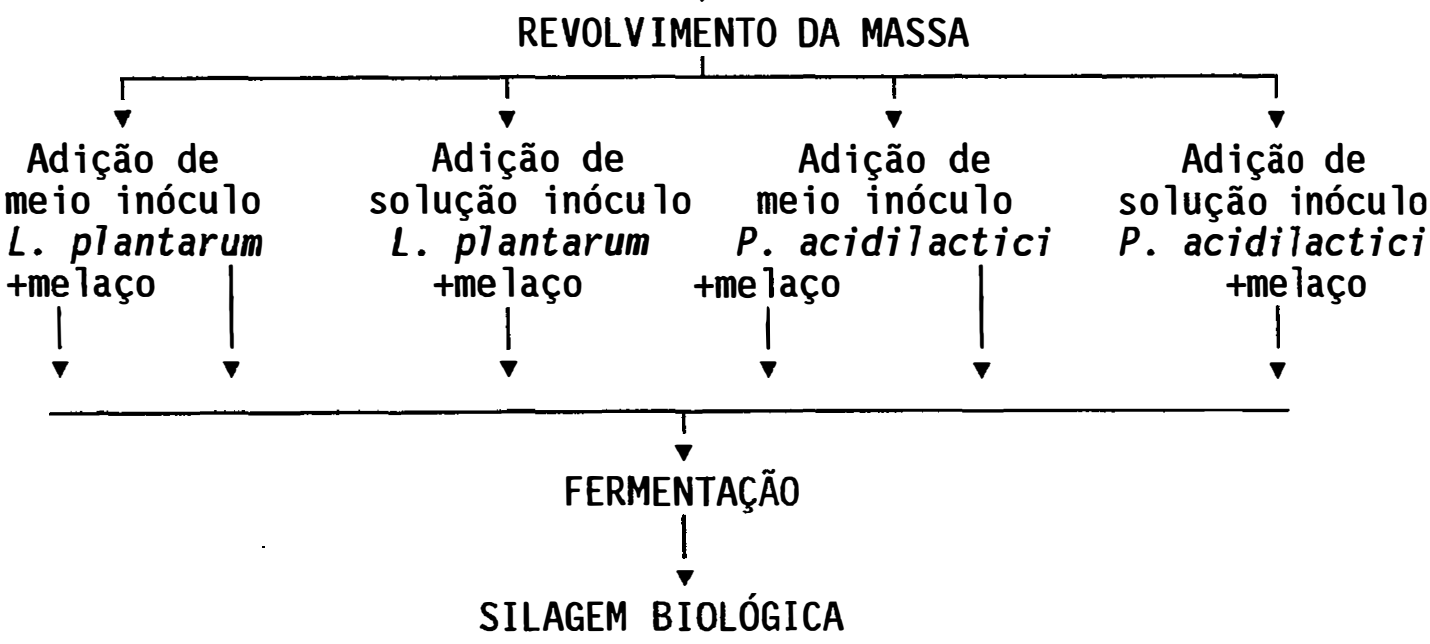

Figura 1. Fluxograma para produção de silagens biológicas de pescado. 


\subsubsection{Etapas do preparo}

A coleta da matéria-prima depende de um manejo planejado ou pré estabelecido a ser implantado na linha de processamento. Assim, este fluxograma, se aplicado na indústria, iniciar-se na etapa de desintegração/homogeneização, seguida do tratamento químico imediato.

Uma triagem se faz necessária, à medida que a empresa se proponha a elaborar a silagem para uso em rações e para consumo humano, pois para este último emprego o descarte das vísceras é imprescindível. Outras partes consideradas não comestíveis, como as cabeças e as caudas, podem, no entanto, tornarem-se comestíveis após o efeito dos ácidos e das enzimas no processamento da silagem.

Pelo fato da silagem como produto para consumo se constituir de um material pastoso, qualquer parte do pescado estará descaracterizada, assim, tecido ósseo, muscular (sobras de filetagem e tecidos mais escuros) ou ainda as escamas estarão compondo uma biomassa única.

Ao se propor que uma experiência de laboratório passe à indústria, devese orientar quanto ao "scale up" do processo. Assim, ao se adotar o fluxograma por nós proposto, a indústria deve planejar a aquisição e a distribuição nas plantas dos tanques para adição de ácidos e da "cultura starter".

$\mathrm{Na}$ industrialização de alimentos do futuro, não haverá perdas desta natureza conforme discutido por vários autores (JONES, 1974; DISNEY, 1977; LISTON, 1977; HORISBERGER, 1979; MORAIS \& MARTINS, 1981; TENUTA 
FILHO, 1983; KARMAS \& LAUBIER, 1987; ALMAS, 1989; OTTATI et al., 1990;

RODRIGUEZ et al., 1990a e b; UNITED Nations..., 1991; BIMBO \& CROWTHER, 1992; GREENSHIELDS, 1992; OETTERER et al., 1992; SANKAR \& SOLANKI, 1992).

A política é fazer com que todo empresário de pesca dê um destino ao material residual para que este seja uma nova fonte de renda, conforme dito por REGENSTEIN (1990), o que é perfeitamente viável seguindo o fluxograma proposto nesta pesquisa.

A silagem química prévia ao preparo de silagem microbiológica conforme indicada no fluxograma para produção da silagem de pescado, é um procedimento simples e de baixo custo, elaborada basicamente conforme preconizado pela maioria dos autores que estudaram silagem de pescado e respeitando o que já está em uso em alguns países europeus (DISNEY et al., 1977; KOMPIANG, 1981; HAARD et al., 1985).

As variações encontradas na literatura estão circunscritas ao aspecto da adição de diferentes ácidos ou misturas de ácidos, além da relação entre eles ou em relação à matéria-prima utilizada.

A adição de ácidos é etapa fundamental para a conservação da biomassa do pescado, constituindo-se em uma primeira etapa indispensável para a elaboração da silagem microbiológica. Assim, no presente estudo utilizou-se a silagem química como pré tratamento à elaboração da silagem microbiana. A incorporação do melaço ao substrato pescado e o uso de microrganismos produtores de ácido lático leva à 
possibilidade de ocorrer uma fermentação que estabiliza o pH do sistema sem que seja excessivamente ácido e produz silagens com melhor cor e aroma mais agradável do que as silagens químicas.

O tratamento ácido é que permite o acúmulo de material residual até volume suficiente para processamento, evitando o descarte periódico de poucos volumes, conforme ocorre na Indonésia, segundo KOMPIANG (1981). Já para a fabricação de farinha de peixes, há necessidade de grandes volumes e desidratação imediata, conforme explicado pelo mesmo autor.

Como inóculo foram empregados o $L$. plantarum e o $P$. acidilactici, ambos produtores de ácido lático, e que segundo LINDGREN \& PLEJE (1983) promovem uma silagem em cerca de 30 horas com $\mathrm{pH} 4,5$.

Como fonte de carbono utilizou-se melaço, por ser uma fonte de carboidrato de baixo custo e por estar disponível nas várias regiões canavieiras.

Segundo WYK \& HEYDENRYCH (1985), quando utilizado melaço e L. plantarum como inóculo, a redução do pH ocorre mais rapidamente que quando se utiliza outra fonte de carboidratos. Neste experimento, porém, partiu-se de silagem acidificada e não da matéria prima.

Quando o L. plantarum e o $P$. acidilactici, são utilizados como cultura inóculo, ocorre uma diminuição rápida do $\mathrm{pH}$ e o produto apresenta alto teor de carboidratos solúveis, o que mostra que estes microrganismos são eficientes no uso dos carboidratos disponíveis, tranformando-os em ácido lático. Além disso, através de síntese de bacteriocinas, há inibição do crescimento de microrganismos putrefativos e 
patogênicos (STANTON \& YEOH, 1977; ICMSF, 1980; ARECHE \& BERENZ, 1987; BORRESEN, 1990; HERON et al., 1993).

\subsubsection{Avaliação sensorial das silagens}

O grau de hidrólise é um critério usado para avaliar a silagem de pescado, e este é diretamente proporcional às alterações da massa, chegando à liquefação ao longo do armazenamento. A avaliação visual, acompanhada da avaliação química, definem o tempo necessário para a comercialização do produto (DISNEY et al., 1977; HAARD et al., 1985; ESPE et al., 1989).

Durante o fermentação das silagens foi observada uma descaracterização da massa, o que está de acordo com TATTERSON \& WINDSOR (1974); DISNEY et al. (1977) e OTTATI et al. (1990).

Pelo exame visual das silagens microbiológicas, observou-se uma alteração da massa, levando a formação de uma massa pastosa que se manteve até o final do experimento, o que está de acordo com HAARD et al. (1985), que afirmam que a proteína da silagem de pescado é continuamente hidrolisada por pelo menos um mês.

As silagens mantiveram uma coloração marrom claro (sem melaço) e marrom escuro (com melaço).

Depois de 2 a 3 dias de fermentação, foram observadas, na superfície da silagem, pequenas cavidades; acredita-se que tenham sido provocadas pela liberação de gases produzidos pelas bactérias ácido láticas durante o processo fermentativo. 
No que se refere ao aroma, todas as silagens apresentaram um aroma agradável, o que está de acordo com JAMES et al. (1977). O aroma ácido, presente na silagem química prévia ao processo de adição do inóculo ficou descaracterizado já nas primeiras etapas da fermentação.

\subsection{Análises químicas}

\subsection{1. $\mathrm{pH}$ das silagens}

Tabela 2. pH das silagens durante as etapas do processo.

\begin{tabular}{llccc}
\hline & $\begin{array}{c}\text { Antes } \\
\text { da adição } \\
\text { do melaço }\end{array}$ & $\begin{array}{c}\text { Após } \\
\text { a adição } \\
\text { do melaço }\end{array}$ & $\begin{array}{c}\text { Após } \\
\text { inoculação } \\
\text { da cultura }\end{array}$ & $\begin{array}{c}\text { Após } \\
\text { dias de } \\
\text { fermentação }\end{array}$ \\
\hline $\begin{array}{l}\text { Silagem: solução inóculo } \\
\text { L. plantarum + melaço }\end{array}$ & 3,83 & 3,78 & 3,84 & 4,18 \\
$\begin{array}{l}\text { Silagem: meio inóculo } \\
\text { L. plantarum }\end{array}$ & 3,83 & & 3,80 & 4,21 \\
$\begin{array}{l}\text { Silagem: meio inóculo } \\
\text { L. plantarum + melaço }\end{array}$ & 3,83 & 3,77 & 3,79 & 4,18 \\
$\begin{array}{l}\text { Silagem: solução inóculo } \\
\text { P. acidilactici + melaço }\end{array}$ & 3,83 & 3,78 & 3,85 & 4,20 \\
$\begin{array}{l}\text { Silagem: meio inóculo } \\
\text { P. acidilactici }\end{array}$ & 3,81 & & & \\
$\begin{array}{l}\text { Silagem: meio inóculo } \\
\text { P. acidilactici + melaço }\end{array}$ & 3,83 & 3,79 & 3,87 & 4,23 \\
\hline
\end{tabular}

$\mathrm{O}$ pH das silagens microbianas ao longo do período estudado variou de 4,18 a 4,25 (Tabela 2), sendo que nas primeiras medições, o pH da silagem química foi de 3,81 a 3,83; após a adição do melaço e do inóculo observou-se ligeiras alterações, 
e ao final do experimento, o pH apresentou-se com valor de até 4,25.

Os valores de pH encontrados nas silagens microbianas estão de acordo com a maioria dos autores que citam como sendo 4,5 um pH suficientemente baixo para garantir o sucesso da fermentação.

A silagem química prévia manteve-se estável ao longo do tempo decorrido da adição dos ácidos até o momento das adições do inóculo e substratos que caracterizam a silagem microbiana. A faixa de $\mathrm{pH}$ 3,81-3,83 proporcionou, junto à ação bactericida do ácido propiônico, um fator de estabilidade, como acontece em trabalhos de alguns autores citados na bibliografia.

$\mathrm{O}$ pH ácido dos sistemas (abaixo de 4,5) aliado a ação bactericida do ácido propiônico são fatores importantes à estabilidade destes. A idéia é a de que a preservação não dependa somente da acidez, mas também da escolha do ácido que tenha uma forte ação bactericida. Nestas circunstâncias, misturas com pH mais alto são aceitáveis (TATTERSON \& WINDSOR, 1974; BACKHOFF, 1976; GILBERT \& RAA, 1977; STROM et al., 1979; KOMPIANG, 1981).

Empregando-se os ácidos orgânicos fórmico e propiônico, obtém-se uma silagem com odor ácido menos pronunciado, embora os ácidos orgânicos sejam mais onerosos do que os minerais; além disso, para a manipulação na indústria, os ácidos orgânicos são menos corrosivos do que os minerais (TATTERSON \& WINDSOR, 1974; DISNEY et al., 1977; KOMPIANG, 1981). 


\subsubsection{Composição centesimal das silagens}

Tabela 3. Teor de umidade e proteína das silagens biológicas nos diferentes tempos de fermentação.

\begin{tabular}{|c|c|c|c|c|}
\hline \multirow[t]{2}{*}{ Amostra } & \multirow[t]{2}{*}{ Tempo } & \multirow{2}{*}{$\begin{array}{l}\text { Umidade } \\
(\mathrm{g} / 100 \mathrm{~g})\end{array}$} & \multicolumn{2}{|c|}{ Proteína (g/100g) } \\
\hline & & & m.u. & m.s. \\
\hline Matéria-prima & & 74,12 & 19,36 & 74,79 \\
\hline $\begin{array}{l}\text { Silagem: solução inóculo } \\
\text { L. plantarum + melaço }\end{array}$ & $\begin{array}{c}48 \mathrm{~h} \\
1 \\
2\end{array}$ & $\begin{array}{l}55,94 \\
54,12 \\
51,94\end{array}$ & $\begin{array}{l}19,33 \\
20,13 \\
21,32\end{array}$ & $\begin{array}{l}43,87 \\
43,87 \\
44,37\end{array}$ \\
\hline $\begin{array}{l}\text { Silagem: meio inóculo } \\
\text { L. plantarum }\end{array}$ & $\begin{array}{c}48 \mathrm{~h} \\
1 \\
2\end{array}$ & $\begin{array}{l}69,64 \\
67,31 \\
64,10\end{array}$ & $\begin{array}{l}20,78 \\
22,15 \\
24,03\end{array}$ & $\begin{array}{l}68,44 \\
67,75 \\
66,94\end{array}$ \\
\hline $\begin{array}{l}\text { Silagem: meio inóculo } \\
\text { L. plantarum + melaço }\end{array}$ & $\begin{array}{c}48 \mathrm{~h} \\
1 \\
2\end{array}$ & $\begin{array}{l}59,74 \\
61,60 \\
58,68\end{array}$ & $\begin{array}{l}17,89 \\
16,08 \\
17,61\end{array}$ & $\begin{array}{l}44,44 \\
41,87 \\
42,62\end{array}$ \\
\hline $\begin{array}{l}\text { Silagem: solução inócu lo } \\
\text { P. acidilactici + melaço }\end{array}$ & $\begin{array}{c}48 \mathrm{~h} \\
1 \\
2\end{array}$ & $\begin{array}{l}58,83 \\
58,66 \\
59,25\end{array}$ & $\begin{array}{l}17,39 \\
17,48 \\
17,40\end{array}$ & $\begin{array}{l}42,25 \\
42,28 \\
42,69\end{array}$ \\
\hline $\begin{array}{l}\text { Silagem: meio inóculo } \\
\text { P. acidilactici }\end{array}$ & $\begin{array}{c}48 \mathrm{~h} \\
1 \\
2\end{array}$ & $\begin{array}{l}68,35 \\
69,91 \\
67,85\end{array}$ & $\begin{array}{l}23,82 \\
20,29 \\
20,74\end{array}$ & $\begin{array}{l}75,25 \\
67,44 \\
64,50\end{array}$ \\
\hline $\begin{array}{l}\text { Silagem: me io inóculo } \\
\text { P. acidilactici }+ \text { melaço }\end{array}$ & $\begin{array}{c}48 \mathrm{~h} \\
1 \\
2\end{array}$ & $\begin{array}{l}68,49 \\
58,35 \\
57,56\end{array}$ & $\begin{array}{l}13,94 \\
16,58 \\
18,17\end{array}$ & $\begin{array}{l}44,25 \\
39,81 \\
42,81\end{array}$ \\
\hline
\end{tabular}

Tempo $48 \mathrm{~h}=$ considerado tempo inicial após 48 horas da adição do inóculo

Tempos 1 e 2 em semanas

Os autores que avaliaram nutricionalmente as silagens são unânimes em afirmar que a sua composição centesimal é semelhante à da matéria prima que deu origem à silagem. A única ressalva que se faz é com relação à pequena diluição provocada pela adição de ácidos e carboidratos (TATTERSON \& WINDSOR, s.d.; 
DISNEY et al., 1977; KOMPIANG, 1981; BROWN \& SUMNER, 1985).

De acordo com a Tabela 3, vê-se que com o passar do tempo de fermentação da silagem, houve diminuição no teor de umidade, provocada pelo ressecamento da massa que foi mantida em beckers ao ambiente.

Assim, os teores encontrados para as silagens preparadas com meio inóculo foram mais elevados, sendo, após 48 horas, 69,64\% e 68,35\% para o $L$. plantarum e o $P$. acidilactici, respectivamente, diminuindo para $64,10 \%$ e 67,85\%, após duas semanas.

A fração protéica das silagens microbianas apresentou-se com teores mais elevados nas silagens que não receberam o melaço, tanto para a silagem preparada com L. plantarum e o $P$. acidilactici, a saber, $68,44 \%$ e $75,25 \%$, respectivamente, no tempo inicial.

JOHNSON et al. (1985) em silagem preparadas com $L$. plantarum e $P$. acidilactici, encontraram o menor teor de proteína bruta, média de $78,7 \%$, nas silagens fermentadas, e de $\mathbf{9 8 , 7 \%}$ nas silagens não fermentadas.

Após uma semana de fermentação das silagens observou-se um leve declínio da fração protéica que foi maior na silagem com $P$. acidilactici, cujo teor chegou a $67,44 \%$ na primeira semana. Após duas semanas, houve queda para $64,50 \%$. Este declínio progressivo na proteína bruta é consequência da hidrólise protéica. No entanto, a hidrólise foi mais acentuada na primeira semana, com perda de $10,37 \%$ de proteína bruta em relação ao tempo inicial e de apenas $4,36 \%$ na segunda semana. 
ESPE et al. (1989) e RAA \& NJAA (1989) explicaram que o maior valor nutritivo da silagem está indiretamente relacionado com o tempo prolongado de estocagem. Assim, em relação apenas à proteína total, podemos dizer que é melhor a utilização da silagem logo após o preparo, e no máximo uma semana de armazenamento. STONE \& HARDY (1986) também concordam que a silagem "fresca" é nutricionalmente superior à silagem estocada, pois com o decorrer do tempo haverá o acúmulo de produtos de degradação.

Estudos realizados por MANIKANDAVELU et al. (1992), em silagem fermentada com $15 \%$ de melaço, encontraram $17 \%$ de proteína na base úmida; já ARECHE \& BERENZ (1987) encontraram o valor de $40 \%$ na base seca. Estes valores se apresentam próximos aos obtidos nas silagens microbianas que receberam melaço.

Assim, nas silagens que foram preparadas com L. plantarum e melaço e com $P$. acidilactici e melaço, tanto na situação de meio inóculo como solução inóculo, observou-se que os valores de proteína bruta, na matéria úmida estiveram na faixa de $13,94 \%$ a $21,32 \%$ em todos os sistemas ensaiados, sendo de $39,81 \%$ a $44,37 \%$ na matéria seca.

A adição do melaço levou a uma diluição do sistema, pela incorporação de umidade e sólidos e conseqüentemente diminuição da proteína bruta, quando se compara com as silagens microbianas, sem adição de melaço.

O uso de meio inóculo ou de solução inóculo não afetou acentuadamente os resultados encontrados para a fração protéica, ambas as fermentações ocorreram. No entanto, o uso de meio inóculo levou, após uma semana de fermentação, a perdas 
relativas mais acentuadas de proteína bruta para ambos os microrganismos estudados; já com a solução inóculo não houve nehuma alteração protéica entre o tempo inicial e uma semana. Pode-se dizer, portanto, que o meio inóculo permitiu melhor trabalho do microrganismo no sistema, o que se refletiu na hidrólise mais acentuada, com conseqüente liberação de aminoácidos.

KOMPIANG et al. (1980), encontrou altos níveis de açúcares remanescentes depois de sete dias de fermentação de peixe com melaço (100:15) e paralelamente encontrou altos níveis de aminoácidos. No entanto, durante o armazenamento prolongado das silagens biológicas pode haver perda de aminoácidos, que podem ser atribuídas às interações com os açúcares remanescentes (JAMES et al., 1977).

A atividade autolítica que ocorre durante o armazenamento de pescado fermentado, aumenta o teor de amônia, aminas, aminoácidos e peptídios, os quais afetam também o poder tampão e podem levar o aumento do pH (LINDGREN \& PLEJE, 1983).

Em relação à fração cinza (Tabela 4) os maiores teores encontrados foram para as mesmas silagens microbianas, a saber, preparadas com $L$. plantarum e P.acidilactici, sem adição de melaço.

Esta fração tem importância por guardar os minerais presentes nas silagens e assim, quanto mais elevada, mais nutritivo será o alimento que ele representa, tanto para uso como ração ou para consumo humano. 
Tabela 4. Teor de cinza e de carboidratos das silagens biológicas nos diferentes tempos de fermentação.

\begin{tabular}{|c|c|c|c|c|}
\hline Amostra & Tempo & $\begin{array}{l}\text { Cinza } \\
\text { m.u. }\end{array}$ & $\begin{array}{c}(\mathrm{g} / 100 \mathrm{~g}) \\
\text { m.s. }\end{array}$ & $\begin{array}{c}\text { Carboidratos } \\
(\mathrm{g} / 100 \mathrm{~g})\end{array}$ \\
\hline Matéria-prima & & 3,61 & 15,95 & 0,54 \\
\hline $\begin{array}{l}\text { Silagem: solução inóculo } \\
\text { L. plantarum + me laço }\end{array}$ & $\begin{array}{c}48 \mathrm{~h} \\
1 \\
2\end{array}$ & $\begin{array}{l}3,77 \\
3,83 \\
4,09\end{array}$ & $\begin{array}{l}8,56 \\
8,36 \\
8,52\end{array}$ & $\begin{array}{l}18,51 \\
19,40 \\
10,29\end{array}$ \\
\hline $\begin{array}{l}\text { Silagem: meio inóculo } \\
\text { L. plantarum }\end{array}$ & $\begin{array}{c}48 h \\
1 \\
2\end{array}$ & $\begin{array}{l}3,73 \\
3,78 \\
4,39\end{array}$ & $\begin{array}{l}12,29 \\
11,58 \\
12,22\end{array}$ & $\begin{array}{l}7,92 \\
3,63 \\
4,07\end{array}$ \\
\hline $\begin{array}{l}\text { Silagem: meio inóculo } \\
L \text {. plantarum + melaço }\end{array}$ & $\begin{array}{c}48 \mathrm{~h} \\
1 \\
2\end{array}$ & $\begin{array}{l}3,01 \\
3,18 \\
3,31\end{array}$ & $\begin{array}{l}7,49 \\
8,28 \\
8,02\end{array}$ & $\begin{array}{l}17,17 \\
17,18 \\
18,31\end{array}$ \\
\hline $\begin{array}{l}\text { Silagem: solução inóculo } \\
\text { P. acidilactici + melaço }\end{array}$ & $\begin{array}{c}48 \mathrm{~h} \\
1 \\
2\end{array}$ & $\begin{array}{l}3,32 \\
4,34 \\
3,50\end{array}$ & $\begin{array}{r}8,06 \\
10,49 \\
8,59\end{array}$ & $\begin{array}{l}18,15 \\
17,16 \\
17,46\end{array}$ \\
\hline $\begin{array}{l}\text { Silagem: meio inóculo } \\
\text { P. acidilactici }\end{array}$ & $\begin{array}{c}48 \mathrm{~h} \\
1 \\
2\end{array}$ & $\begin{array}{l}3,77 \\
3,74 \\
3,95\end{array}$ & $\begin{array}{l}11,92 \\
12,43 \\
12,30\end{array}$ & $\begin{array}{l}1,30 \\
3,54 \\
4,74\end{array}$ \\
\hline $\begin{array}{l}\text { Silagem: meio inóculo } \\
\text { P. acidilactici + melaço }\end{array}$ & $\begin{array}{c}48 \mathrm{~h} \\
1 \\
2\end{array}$ & $\begin{array}{l}2,70 \\
2,26 \\
3,75\end{array}$ & $\begin{array}{l}8,58 \\
7,84 \\
8,84\end{array}$ & $\begin{array}{l}12,91 \\
20,08 \\
18,18\end{array}$ \\
\hline
\end{tabular}

Tempo $48 \mathrm{~h}=$ tempo inicial

Tempos 1 e 2 em semanas

m.u. = matéria úmida

m.s. = matéria seca.

Os carboidratos presentes nas silagens são contribuição exclusiva do melaço adicionado. As silagens preparadas com adição de meio inóculo poderiam eventualmente, apresentar teores razoáveis de carboidratos totais, porém, pelos teores encontrados, de $4,07 \%$ e $4,74 \%$ para as silagens preparadas com $L$. plantarum e $P$. acidilactici, após duas semanas de fermentação, entende-se que, efetivamente, os microrganismos utilizaram-se dos meios, havendo, provavelmente, maior consumo dos carboidratos do meio, do que dos carboidratos do melaço, considerando cada uma das 
silagens isoladamente.

As silagens preparadas com os microrganismos e os meios foram comparadas com as silagens nas quais utilizou-se o melaço como fonte de carbono, pois na prática o microrganismo deverá ser inoculado na massa homogênea dos resíduos de pescado e terá como fonte de carbono para seu crescimento, o melaço.

Tabela 5. Teor de lipídios das silagens biológicas nos diferentes tempos de fermentação.

\begin{tabular}{|c|c|c|c|}
\hline \multirow[b]{2}{*}{ Amostra } & \multirow[b]{2}{*}{ Tempo } & \multicolumn{2}{|c|}{ Lipídios $(\mathrm{g} / 100 \mathrm{~g})$} \\
\hline & & m.u. & m.s. \\
\hline Matéria-prima & & 2,37 & 9,16 \\
\hline $\begin{array}{l}\text { Silagem: solução inóculo } \\
\text { L. plantarum + melaço }\end{array}$ & $\begin{array}{c}48 h \\
1 \\
2\end{array}$ & $\begin{array}{l}2,45 \\
2,52 \\
2,63\end{array}$ & $\begin{array}{l}5,56 \\
5,49 \\
5,48\end{array}$ \\
\hline $\begin{array}{l}\text { Silagem: meio inóculo } \\
\text { L. plantarum }\end{array}$ & $\begin{array}{c}48 h \\
1 \\
2\end{array}$ & $\begin{array}{l}2,93 \\
3,13 \\
3,41\end{array}$ & $\begin{array}{l}9,65 \\
9,58 \\
9,50\end{array}$ \\
\hline $\begin{array}{l}\text { Silagem: meio inóculo } \\
\text { L. plantarum + melaço }\end{array}$ & $\begin{array}{c}48 h \\
1 \\
2\end{array}$ & $\begin{array}{l}2,19 \\
1,96 \\
2,09\end{array}$ & $\begin{array}{l}5,45 \\
5,11 \\
5,07\end{array}$ \\
\hline $\begin{array}{l}\text { Silagem: solução inóculo } \\
\text { P. acidilactici + melaço }\end{array}$ & $\begin{array}{c}48 h \\
1 \\
2\end{array}$ & $\begin{array}{l}2,31 \\
2,36 \\
2,39\end{array}$ & $\begin{array}{l}5,61 \\
5,71 \\
5,86\end{array}$ \\
\hline $\begin{array}{l}\text { Silagem: meio inóculo } \\
\text { P. acidilactici }\end{array}$ & $\begin{array}{c}48 \mathrm{~h} \\
1 \\
2\end{array}$ & $\begin{array}{l}2,76 \\
2,52 \\
2,72\end{array}$ & $\begin{array}{l}8,73 \\
8,37 \\
8,45\end{array}$ \\
\hline $\begin{array}{l}\text { Silagem: meio inóculo } \\
\text { P. acidilactici }+ \text { melaço }\end{array}$ & $\begin{array}{c}48 \mathrm{~h} \\
1 \\
2\end{array}$ & $\begin{array}{l}1,96 \\
1,93 \\
2,34\end{array}$ & $\begin{array}{l}6,22 \\
4,63 \\
5,51\end{array}$ \\
\hline
\end{tabular}

Tempo $48 \mathrm{~h}=$ tempo inicial para as silagens biológicas

Tempos 1 e 2 em semanas

m.u. = matéria úmida

m.s. = matéria seca. 
Os teores de lipídios das silagens apresentados na Tabela 5 variam de $1,93 \%$ a $2,93 \%$ na base úmida, porém os maiores valores foram os encontrados nas silagens preparadas com meio inóculo tanto com o $L$. plantarum como com o $P$. acidilactici, sem adição de melaço, onde não houve portanto, o efeito da diluição provocada por este.

Observa-se, que de uma forma geral há uma tendência à dimuição no teor de lipídios com o decorrer dos processos, o que é favorável, já que segundo DISNEY et al. (1977); WINDSOR (1979); STROM \& EGGUM (1981), a fração lipídica pode ser considerada como um interferente e portanto recomenda que seja removida do processo, no caso da silagem química.

A fração lipídica interferente foi discutida pelos autores citados acima, como sendo responsável pelo escurecimento da silagem após, sofrer oxidação. Há também, segundo DISNEY et al. (1977), a possibilidade de ocorrer hidrólise dos glicerídeos por enzimas presentes no sistema.

Para STROM \& EGGUM (1981), a remoção dos lipídios proporcionaria ainda um aumento do aproveitamento das proteína da silagem como alimento.

No entanto, a operação de remoção dos lipídios é onerosa, se feita por extração com solventes, conforme discutido por WINDSOR (1979), e no presente experimento objetivou-se a produção de silagem de baixo investimento. Complementarmente a este fato, a remoção não se justificaria por serem baixos os teores de lipídios encontrados nos processos e nos diferentes períodos analisados. 


\subsubsection{Composição em ácidos graxos da fração lipídica das silagens}

Tabela 6. Composição em ácidos graxos da fração lipídica das silagens biológicas com L. plantarum nos diferentes tempos de fermentação ( $\mathrm{g} / 100 \mathrm{~g}$ lipídeos). AMOSTRAS

\begin{tabular}{|c|c|c|c|c|c|c|c|c|c|c|c|}
\hline & & \multirow{2}{*}{$\begin{array}{l}\text { Matéria } \\
\text { Prima }\end{array}$} & \multicolumn{3}{|c|}{$\begin{array}{l}\text { Silagem solução } \\
\text { inóculo + melaço }\end{array}$} & \multicolumn{3}{|c|}{$\begin{array}{l}\text { Silagem meio } \\
\text { inóculo }\end{array}$} & \multicolumn{3}{|c|}{$\begin{array}{l}\text { Silagem meio } \\
\text { inóculo + melaço }\end{array}$} \\
\hline & & & $48 \mathrm{~h}$ & 1 sem & $2 \mathrm{sem}$ & $48 \mathrm{~h}$ & $1 \mathrm{sem}$ & 2 sem & $48 \mathrm{~h}$ & $1 \mathrm{sem}$ & $2 \mathrm{sem}$ \\
\hline $14: 0$ & Mistírico & 5,87 & 7,00 & 7,35 & 6,27 & 7,26 & 7,23 & 7,58 & 7,67 & 7,90 & 7,37 \\
\hline $15: 0$ & Pentadecanóico & 0,83 & $\operatorname{tr}$ & $\operatorname{tr}$ & $\operatorname{tr}$ & 1,11 & 1,21 & 1,44 & 1,03 & 1,25 & 1,20 \\
\hline $16: 0$ & Palmítico & 17,70 & 24,11 & 26,57 & 21,03 & 30,39 & 30,82 & 30,42 & 29,14 & 29,68 & 28,61 \\
\hline $16: 1$ & Palmitoléico & 17,47 & 11,65 & 9,48 & 16,55 & 9,34 & 9,06 & 7,60 & 9,78 & 8,75 & 9,00 \\
\hline $17: 0$ & Heptadecanóico & 1,86 & 0,81 & 1,23 & 1,65 & 1,15 & 0,85 & 1,82 & tr & 1,04 & 1,05 \\
\hline $18: 0$ & Esteárico & 4,22 & 5,27 & 5,32 & 4,51 & 7,32 & 7,05 & 7,32 & 6,86 & 6,72 & 6,58 \\
\hline $18: 1$ & Oléico & 12,01 & 12,67 & 11,28 & 12,79 & 11,31 & 11,14 & 11,45 & 10,42 & 10,48 & 11,70 \\
\hline $18: 2$ & Linoléico & 1,86 & 1,14 & 0,69 & 1,75 & 1,70 & 1,52 & 1,40 & 1,52 & 1,66 & 1,38 \\
\hline $18: 3$ & Linolênico & 3,74 & 1,93 & 3,12 & 3,20 & 0,63 & 0,59 & 0,67 & 1,15 & 0,56 & 0,83 \\
\hline $18: 4$ & Octadecatetraenóico & co 1,55 & 0,94 & 1,43 & 1,24 & 0,68 & 0,54 & 0,86 & 0,87 & 0,58 & 0,94 \\
\hline $20: 4$ & Araquidônico & 1,37 & 0,85 & 0,87 & 0,91 & 1,31 & 1,32 & 1,52 & 1,57 & 1,18 & 1,52 \\
\hline $20: 5$ & Eicosapentaenóico & 8,24 & 8,16 & 8,16 & 7,01 & 5,63 & 6,49 & 6,19 & 6,18 & 6,53 & 6,28 \\
\hline $22: 5$ & Docosapentaenóico & 0,95 & 0,97 & 0,87 & $\operatorname{tr}$ & 0,57 & 0,51 & 0,75 & 0,82 & 0,71 & 0,67 \\
\hline $22: 6$ & Docosahexaenóico & 17,40 & 19,14 & 18,68 & 18,21 & 14,58 & 14,92 & 13,84 & 15,36 & 15,03 & 14,36 \\
\hline
\end{tabular}

Conforme apresentado na Tabela 6, os ácidos graxos presentes na fração lipídica do material residual de sardinhas são predominantemente os insaturados, como palmitolêico, 17,47\%; o desosahexaenóico, $17,40 \%$ e o oléico, $12,01 \%$. Dentre os saturados o palmítico aparece em maior quantidade, $17,70 \%$ 
Tabela 7. Composição em ácidos graxos da fração lipídica das silagens biológicas com R.acidilactici nos diferentes tempos de fermentação ( $\mathrm{g} / \mathrm{l} 00 \mathrm{~g}$ lipídios). AMOSTRAS

\begin{tabular}{|c|c|c|c|c|c|c|c|c|c|c|c|}
\hline & & \multirow{2}{*}{$\begin{array}{l}\text { Matéria } \\
\text { Prima }\end{array}$} & \multicolumn{3}{|c|}{$\begin{array}{l}\text { Silagem solução } \\
\text { inóculo + melaço }\end{array}$} & \multicolumn{3}{|c|}{$\begin{array}{l}\text { Silagem meio } \\
\text { inóculo }\end{array}$} & \multicolumn{3}{|c|}{$\begin{array}{l}\text { Silagel meio } \\
\text { inóculo + melaço }\end{array}$} \\
\hline & & & $48 \mathrm{~h}$ & 1 sem & $2 \mathrm{sem}$ & $48 \mathrm{~h}$ & $1 \mathrm{sem}$ & $2 \mathrm{sem}$ & $48 \mathrm{~h}$ & $1 \mathrm{sem}$ & 2 sem \\
\hline $14: 0$ & Mistírico & 5,87 & 7,03 & 7,12 & 6,66 & 6,87 & 6,75 & 6,21 & 7,17 & 8,32 & 7,92 \\
\hline 15:0 & Pentadecanóico & 0,83 & 1,03 & 0,77 & 1,02 & 0,85 & 1,08 & 1,11 & 0,97 & 1,43 & 1,24 \\
\hline $16: 0$ & Palmítico & 17,70 & 27,33 & 27,73 & 25,75 & 21,56 & 22,76 & 20,22 & 30,50 & 32,48 & 31,21 \\
\hline $16: 1$ & Palmitoléico & 17,47 & 8,33 & 11,00 & 8,27 & 17,03 & 16,45 & 19,39 & 13,60 & 9,70 & 9,48 \\
\hline $17: 0$ & Heptadecanóico & 1,86 & 0,95 & 1,44 & 1,19 & 1,87 & 2,32 & 1,86 & 0,89 & 0,88 & 1,67 \\
\hline $18: 0$ & Esteárico & 4,22 & 6,01 & 5,03 & 5,59 & 2,80 & 4,79 & 4,51 & 5,71 & 7,25 & 6,83 \\
\hline $18: 1$ & Oléico & 12,01 & 9,47 & 8,52 & 11,24 & 15,17 & 13,55 & 13,27 & 9,93 & 11,61 & 9,85 \\
\hline $18: 2$ & Linoléico & 1,86 & 1,24 & 0,90 & 1,56 & 2,36 & 2,31 & 2,29 & 0,94 & 1,65 & 1,17 \\
\hline $18: 3$ & Linolênico & 3,74 & 0,72 & $\operatorname{tr}$ & 0,67 & 2,94 & 3,09 & 3,07 & 0,63 & 1,00 & 0,70 \\
\hline $18: 4$ & octadecatetraenóic & co 1,55 & 1,01 & 0,86 & 0,86 & 1,28 & 1,07 & 1,00 & 0,74 & 0,74 & 0,78 \\
\hline $20: 4$ & Araquidônico & 1,37 & 1,63 & 1,49 & 1,39 & 0,87 & 1,27 & 6,90 & 1,29 & 1,32 & 1,44 \\
\hline $20: 5$ & Eicosapentaenóico & 8,24 & 7,63 & 8,65 & 8,33 & 6,22 & 5,89 & 5,92 & 6,36 & 5,00 & 5,61 \\
\hline $22: 5$ & Docosapentaenóico & 0,95 & 0,86 & 0,56 & 0,91 & 0,60 & $\operatorname{tr}$ & $\operatorname{tr}$ & tr & tr & 0,48 \\
\hline $22: 6$ & Docosahexaenóico & 17,40 & 18,74 & 19,41 & 18,62 & 14,58 & 13,65 & 15,23 & 12,98 & 10,52 & 14,05 \\
\hline
\end{tabular}

De um modo geral não se observa uma tendência de aumento ou diminuição característica para cada ensaio, ou com os diferentes microrganismos ou mesmo com adição ou não de melaço.

Em alguns casos, isoladamente pode-se, observar que para a silagem com meio inóculo de $P$. acidilactici indicadas na Tabela 7 como as amostras 13,14 e 
do que nos mesmos tratamentos com adição de melaço, onde estes valores passam a ser 9,93\%, 11,61\% e 9,85\%, respectivamente (amostras 16, 17 e 18). Esta mesma observação pode ser feita para os ácidos palmitolêico, heptadecanóico, linoléico, linolênico, octodecatetraenóico e docosahexaenóico (Tabelas 6 e 7).

A oxidação dos ácidos insaturados é discutida por alguns autores que afirmam, por esta razão, que a fração lipídica é indesejável na silagem (TATTERSON \& WINDSOR, s.d.). A fermentação microbiana altera a composição em proteína e provoca decréscimo no teor de lipídios, no índice de peróxidos e no índice de ácido tiobarbitúrico, aumentando as bases nitrogenadas voláteis e os ácidos graxos com configuração ômega-3 (YONE et al., 1986; HOSSAIN et al. (1987). O aumento dos ácidos graxos livres pode chegar a um índice de 50-60, o que corresponde a cerca de $20 \%$ de ácidos graxos livres durante a estocagem, conforme experimentos de STROM et al. (1979). Um teor de até 3\% de ácidos graxos livres é desejável para que não haja escurecimento da silagem (DISNEY et al., 1977). Além disso, para KOMPIANG (1981), há uma relação direta entre o escurecimento provocado por reações com a perda do valor nutricional.

No presente experimento, ao se observar os diferentes tratamentos e o comportamento dos ácidos graxos após 48 horas, uma semana e duas semanas, vê-se que os valores praticamente não se alteram com o passar do tempo e, portanto, os ácidos graxos presentes não estão sofrendo reações indesejáveis como enfatizam os autores citados acima. Também não se observa tendências para os diferentes tratamentos quando comparados entre sí e para os diferentes tempos. 
No entanto, ao se comparar cada tratamento nos vários tempos definidos no nosso estudo, pode-se destacar algumas alterações mais acentuadas, como por exemplo, o ácido palmitolêico que, de que $9,48 \mathrm{~g} / 100 \mathrm{~g}$ na silagem com solução inóculo de $L$. plantarum com melaço, após uma semana, passam para $16,55 \mathrm{~g} / 100 \mathrm{~g}$ após duas semanas. Também para este mesmo ácido, na silagem com o meio inóculo de $P$. acidilactici adicionado de melaço após 48 horas, o valor é de $13,60 \mathrm{~g} / 100 \mathrm{~g}$, que passa a 9,70 g/100g após uma semana e praticamente se mantém neste valor até o final do experimento $(9,48 \mathrm{~g} / 100 \mathrm{~g})$. 


\subsubsection{Fração nitrogenada das silagens}

Os teores de nitrogênio total, nitrogênio não protéico e nitrogênio protéico nas silagens biológicas nos diferentes tempos de fermentação podem ser observados na Tabela 8.

Tabela 8. Teores de nitrogênio total, nitrogênio não protéico e nitrogênio protéico nas silagens biológicas nos diferentes tempos de fermentação.

\begin{tabular}{lcccc}
\hline & & \multicolumn{3}{c}{ Nitrogênio* } \\
\cline { 3 - 5 } Amostra & Tempo & $\begin{array}{c}\text { Total } \\
(\%)\end{array}$ & $\begin{array}{c}\text { Não protéico } \\
(\%)\end{array}$ & $\begin{array}{c}\text { Protéico } \\
(\%)\end{array}$ \\
\hline Matéria-prima & & 11,97 & 2,33 & 9,63 \\
Silagem: solução inócu lo & $48 \mathrm{~h}$ & 7,02 & 2,47 & 4,55 \\
L. plantarum + me laço & 1 & 7,02 & 2,69 & 4,33 \\
& 2 & 7,10 & 2,43 & 4,67 \\
Silagem: meio inóculo & $48 \mathrm{~h}$ & 10,95 & 2,32 & 8,63 \\
L. plantarum & 1 & 10,84 & 2,48 & 8,36 \\
& 2 & 10,71 & 2,55 & 8,16 \\
Silagem: meio inóculo & $48 \mathrm{~h}$ & 7,11 & 2,32 & 4,79 \\
L. plantarum + melaço & 1 & 6,70 & 2,48 & 4,22 \\
& 2 & 6,82 & 2,55 & 4,27 \\
Silagem: solução inócu lo & $48 \mathrm{~h}$ & 6,76 & 2,69 & 4,07 \\
P. acidilactici + melaço & 1 & 6,76 & 2,96 & 3,80 \\
& 2 & 6,83 & 2,85 & 3,98 \\
Silagem: meio inóculo & $48 \mathrm{~h}$ & 12,04 & 4,09 & 7,14 \\
P. acidilactici & 1 & 10,79 & 4,93 & 5,86 \\
& 2 & 10,32 & 4,79 & 5,53 \\
Silagem: meio inóculo & $48 \mathrm{~h}$ & 7,08 & 3,04 & 4,04 \\
P. acidilactici + melaço & 1 & 6,37 & 2,45 & 3,92 \\
& 2 & 6,85 & 3,11 & 3,74 \\
\hline
\end{tabular}

* Em matéria seca

Tempo 48h = Tempo inicial

Tempos 1 e 2 semanas 
A fração nitrogenada das silagens foi analisada, levando-se em conta os valores de nitrogênio total, nitrogênio protéico, nitrogênio não protéico, digestibilidade "in vitro" e "in vivo".

Conforme se observa na Tabela 8 , os valores de nitrogênio total mostraram uma tendência de queda ao longo do experimento quando comparados com a matéria prima, evidentemente provocada pelo efeito da diluição provocada nos experimentos após a adição dos inóculos e do melaço.

Tabela 9. Digestibilidade "in vitro" das silagens biológicas nos diferentes tempos de fermentação.

\begin{tabular}{lcc}
\hline Amostra & Tempo & Digestibilidade (\%) \\
\hline Matéria-prima & & 67,6 \\
Silagem: solução inócu lo & 48 horas & 84,2 \\
L. plantarum + melaço & 1 semana & 83,8 \\
& 2 semanas & 83,5 \\
Silagem: meio inóculo & 48 horas & 90,1 \\
L. plantarum & 1 semana & 90,8 \\
& 2 semanas & 86,2 \\
Silagem: meio inóculo & 48 horas & 85,1 \\
L. plantarum + melaço & 1 semana & 84,8 \\
& 2 semanas & 84,2 \\
Silagem: solução inócu lo & 48 horas & 84,5 \\
P. acidilactici + melaço & 1 semana & 82,6 \\
& 2 semanas & 81,0 \\
Silagem: meio inóculo & 48 horas & 88,9 \\
P. acidilactici & 1 semana & 89,0 \\
& 2 semanas & 88,7 \\
Silagem: meio inóculo & 48 horas & 85,7 \\
P. acidilactici + melaço & 1 semana & 82,5 \\
& 2 semanas & 85,4 \\
\hline
\end{tabular}


A passagem do nitrogênio protéico a não proteíco é fundamental para se aferir o grau de hidrólise ocorrida no experimento. Os dados encontrados no presente trabalho concordam com este fato e com os dados da literatura, porém as transformações ocorridas na fração nitrogenada não foram da mesma magnitude por eles relatada.

TATTERSON \& WINDSOR (1974), estudaram as modificações da fração nitrogenada, indicando que ocorre uma hidrólise rápida das proteínas de baixo peso molecular de $75-85 \%$.

BACKHOFF (1976), sob condições de estudo analisou silagem preparada com vísceras de bacalhau e verificou que a formação de nitrogênio não protéico é inversamente proporcional aos valores de nitrogênio protéico após a estocagem.

SALES et al (1992) elaboraram silagem de tilápia (Saratherodon niloticus) com a utilização de ácido fórmico a 3\%, e como no nosso estudo, o processo de autólise foi conduzido a temperatura ambiente. Após 5 dias de experimento à transformação de nitrogênio total a nitrogênio não protéico foi da ordem de 55-60\%.

No presente experimento, após processo fermentativo de 48 horas, 1 e 2 semanas, para a silagem meio inóculo $P$. acidilactici, observou-se que 33,97\%, 45,69 e $46,41 \%$, respectivamente, do nitrogênio total estava sob a forma de nitrogênio não protéico, constituindo-se nos maiores valores encontrados.

Em relação à matéria prima, houve um aumento de mais de $50 \%$ de nitrogênio não protéico em todos os períodos analisados nestas silagens, definindo assim a hidrólise e a digestão das proteínas. 
JAMES et al. (1977) explicam que a baixa digestão das proteínas em silagens fermentadas é devida à preservação parcial exercida pelo ácido lático produzido.

A adição de melaço não alterou acentuadamente a relação nitrogênio não protéico/nitrogênio total, pois para o mesmo microrganismo $P$. acidilactici, solução inóculo mais melaço, discutido acima, encontraram-se os seguintes valores: $39,79 \%$, $43,78 \%$ e $41,73 \%$. Consequentemente, pode-se adicionar o melaço como fonte de carboidrato, sem prejudicar a digestão proteíca no sistema.

O tempo mais prolongado de fermentação não favoreceu, de modo geral, esta hidrólise, pois, para as três silagens preparadas com $L$. plantarum, após uma semana e após duas semanas encontraram-se para a solução inóculo mais melaço, meio inóculo e meio inóculo mais melaço, respectivamente, os valores: $38,31 \%$ e $34,22 \%$; $22,87 \%$ e $23,80 \% ; 37,01 \%$ e $37,39 \%$. O mesmo ocorreu para o $P$. acidilactici, com os valores: $43,78 \%$ e $41,73 \% ; 45,69 \%$ e $46,41 \% ; 38,46 \%$ e $45,40 \%$.

Esta discussão pode ser complementada pelos valores de digestibilidade analisados "in vitro" inicialmente e sequencialmente "in vivo".

Segundo ESPE et al. (1989) E RAA \& NJAA (1989), o valor nutricional da silagem pode ser inferido, mas não totalmente confirmado, por este parâmetro. Sua utilidade é importante como sendo um índice químico da qualidade que deve ser completado por outros índices.

Quanto à digestibilidade "in vitro" (Tabela 9) todas as silagens apresentaram uma digestibilidade maior do que a da matéria prima $(67,60 \%)$, situando-se entre $81,0 \%$ a $90,8 \%$, verificando-se uma leve tendência à diminuição com o decorrer 
do processo.

Pode-se dizer, portanto, que as silagens levaram a um benefício do material residual do pescado, transformando-o em um alimento, com textura uniforme (pasta),de aroma agradável e de maior digestibilidade do que a matéria prima.

Este parâmetro, digestibilidade, reforça as observações feitas nas análises da fração nitrogenada.

O melhor sistema, considerando este parâmetro isoladamente, é o meio inóculo com $L$. plantarum, que chegou a 90,8\% de digestibilidade após uma semana de ensaio. No entanto, o $P$. acidilactici teve comportamento semelhante, pois atingiu $89,0 \%$ de digestibilidade após o mesmo tempo.

Também, pode-se afirmar que os microrganismos bioconverteram o sistema protéico do material residual, embora, nestes dois exemplos citados acima, eles estivessem trabalhando com auxílio dos meios. Ao se adicionar melaço, os valores vão para $84,8 \%$ e $82,5 \%$, respectivamente. E quando se trabalhou com melaço, porém com células suspensas em solução salina, estes valores, praticamente, mantiveram a digestibilidade semelhante, de $83,8 \%$ e $82,6 \%$. Realmente será este último o ensilado preparado pela indústria. E neste caso, o tempo de duas semanas praticamente não alterou o valor da digestibilidade "in vitro", que foi de $83.5 \%$ e $81,0 \%$ e pode, portanto, ser considerado como um período de fermentação até a distribuição do produto 


\subsubsection{Ensaio biológico}

De acordo com a análise estatística, com relação ao coeficiente de eficiência alimentar (CEA), das dietas experimentais a dieta I foi a que apresentou um melhor desempenho $(0,22)$ seguida da dieta III $(0,14)$ e por último a dieta II $(0,09)$; todas as dietas apresentaram um CEA inferior ao da caseina $(0,31)$.

Tabela 10. Peso inicial, peso final, ganho de peso e consumo de ração das dietas experimentais das diferentes silagens.

\begin{tabular}{lcccc}
\hline Dietas & $\begin{array}{c}\text { Peso } \\
\text { Inicial }\end{array}$ & $\begin{array}{c}\text { Peso } \\
\text { Final }\end{array}$ & $\begin{array}{c}\text { Ganho de } \\
\text { Peso }\end{array}$ & $\begin{array}{c}\text { Consumo } \\
\text { Ração }\end{array}$ \\
\hline Dieta I & 45,78 & 126,33 & $80,50^{\mathrm{a}}$ & $368,48^{\mathrm{a}}$ \\
Dieta II & 43,65 & 65,10 & $21,45^{\mathrm{c}}$ & $216,67^{\mathrm{a}}$ \\
Dieta II I & 47,93 & 93,03 & $45,10^{\mathrm{b}}$ & $304,88^{\mathrm{b}}$ \\
Dieta IV & 49,20 & 144,30 & $95,10^{\mathrm{a}}$ & $298,18^{\mathrm{c}}$ \\
\hline
\end{tabular}

* Médias com letras diferentes diferem significativamente a nível de $0,05 \%$.

Dieta $I$ = Silagem meio inóculo de $L$. plantarum + silagem meio inóculo de $P$. acidilactici.

Dieta II = Silagem meio inóculo de $L$. plantarum + silagem meio inóculo de $P$. acidilactici + melaço.

Dieta III = Silagem solução inóculo de L. plantarum + silagem solução inóculo de $P$. acidilactici + melaço.

Dieta IV = Caseína (Padrão). 
Tabela 11. Coeficiente de Eficiência Alimentar (CEA), Razão de Eficiência Protéica (PER), Digestibilidade (D\%), Utilização Protéica Líquida (NPU) e Valor Biológico (VB), para as dietas experimentais das diferentes silagens.

\begin{tabular}{llllll}
\hline $\begin{array}{l}\text { Dietas } \\
\text { Experimentais }\end{array}$ & CEA & PER & D(\%) & NPU (\%) & VB (\%) \\
\hline Dieta I & $0,22^{\mathrm{b}}$ & $2,14^{\mathrm{b}}$ & $93,11^{\mathrm{b}}$ & $51,41^{\mathrm{b}}$ & $55,23^{\mathrm{b}}$ \\
Dieta I I & $0,09^{\mathrm{a}}$ & $0,91^{\mathrm{a}}$ & $96,76^{\mathrm{a}}$ & $30,87^{\mathrm{c}}$ & $31,90^{\mathrm{c}}$ \\
Dieta II & $0,14^{\mathrm{c}}$ & $1,47^{\mathrm{c}}$ & $96,31^{\mathrm{a}}$ & $38,68^{\mathrm{c}}$ & $40,19^{\mathrm{c}}$ \\
Dieta IV & $0,31^{\mathrm{a}}$ & $3,10^{\mathrm{a}}$ & $92,90^{\mathrm{b}}$ & $85,14^{\mathrm{a}}$ & $91,60^{\mathrm{a}}$ \\
\hline
\end{tabular}

* Médias com letras diferentes diferem significativamente a nível de $0,05 \%$.

Dieta I = Silagem meio inóculo de L. plantarum + silagem meio inóculo de $P$. acidilactici.

Dieta II = Silagem meio inóculo de L. plantarum + silagem meio inóculo de $P$. acidilactici + melaço.

Dieta III $=$ Silagem solução inóculo de L. plantarum + silagem solução inóculo de $P$. acidilactici + melaço.

Dieta IV = Caseína (Padrão).

Quanto ao consumo de ração, todas as dietas apresentaram diferença significativa, porém o maior consumo de ração foi para a dieta I $(368,48 \mathrm{~g})$ e, em ordem decrescente a dieta III $(304,88 \mathrm{~g})$, a dieta padrão caseína $(298,18 \mathrm{~g})$ e, por último a dieta II $(216,67 \mathrm{~g})$. Embora o consumo de ração fosse diferente para todas as dietas, analisando, estatisticamente, a variável ganho de peso, encontramos que a diferença no parâmetro consumo de ração não se reflete no ganho de peso. Assim, a dieta padrão caseina foi a que melhor se comportou $(95,10 \mathrm{~g})$, seguida da dieta $\mathrm{I}(80,50 \mathrm{~g})$ não havendo diferença significativa a nível de $0,05 \%$, porém a dieta III $(45,10 \mathrm{~g})$ e a dieta II $(21,45 \mathrm{~g})$ foram diferentes entre si quando comparadas com as dietas padrão caseina e I a nível de $0,05 \%$. 
Analisando os dados obtidos para a taxa de eficiência protéica (PER) das silagens, todos os resultados apresentam diferenças significativas, sendo que, como era de se esperar, a que melhor se comportou foi a dieta padrão caseina $(3,10)$, sendo que para as dietas experimentais a que apresentou um melhor desempenho foi a dieta I $(2,14)$, seguida da dieta III $(1,47)$, e a que apresentou um menor índice de conversão da proteína foi a dieta II, com 0,91 .

Estes valores são inferiores aos encontrados por RODRIGUEZ et al. (1990b) que avaliando silagem química elaboradas a partir da fauna de acompanhamento do camarão encontraram um PER de 2,29.

Analisando o parámetro digestibilidade (D\%), encontramos que as dietas II e III não diferem entre si $(96,76$ e $96,31 \%)$, mas diferem da dieta I $(93,11 \%)$ e da dieta padrão caseina $(92,90 \%)$; portanto a dieta I $(93,11 \%)$ pode ser considerada igual a dieta padrão caseína $(92,90 \%)$.

ESPE et al. (1989) em silagens químicas após 15 dias de armazenamento, encontraram 98,5\% de digestibilidade e RODRIGUEZ et al. (1990b) encontraram $90,52 \%$. Os valores encontrados no presente trabalho estão de acordo com os valores encontrados por BROWN \& SUMNER (1985), que foram de 96 a $97 \%$.

Quanto aos valores de utilização protéica líquida (NPU), todos os dados obtidos apresentam diferenças significativas exceto a dieta III $(38,68 \%)$ e a dieta II (30,87\%), para a dieta padrão caseina foram de $85,14 \%$ e de $51,41 \%$ para a dieta $I$.

Segundo ESPE et al. (1989), em suas experiências com silagem química, encontraram valores para NPU de 75,4\%, o qual é maior que o maior valor encontrado 
no nosso trabalho $51,41 \%$ para a dieta I.

No que se refere ao valor biológico (VB), houve diferenças,-exceto para as dietas II e III (31,90\% e 40,19\%), as quais não apresentaram diferença significativa, sendo que a melhor, para esse parâmetro, foi a dieta I com um valor de 55,23\%, seguida da dieta III, e por último, a dieta II. Entretanto, ESPE et al. (1989) encontraram valores de $76,6 \%$, muito acima nos encontrados no presente trabalho.

Considerando todos os parâmetros avaliados, pode-se dizer que as silagens apresentam dados inferiores aos da caseina, o que está dentro do esperado, à exceção do parâmetro digestibilidade que foi maior nas dietas experimentais.

Segundo HASSAN \& HEATH (1987), a digestibilidade é maior como consequência do aumento do nitrogênio solúvel, devido a degradação protéica, a partir da qual espera-se também um aumento nos níveis de aminoácidos de cadeia curta, assim como também de peptídios. Aparentemente essas diferenças na composição dos aminoácidos ocorrem devido à combinação de fatores associados com as alterações físicas e químicas durante a fermentação. Estas alterações podem afetar a biodisponibilidade de proteína e resultam em diferenças na conversão da ração, além de afetar o crescimento. Altos níveis de aminoácidos na dieta podem interferir no mecanismo de absorção de peptídios. Os níveis plasmáticos de aminoácidos após o período de ingestão, são afetados pela absorção seletiva de aminoácidos essenciais (STONE \& HARDY, 1986).

Apesar da digestibilidade ser alta nas dietas experimentais, o ganho de peso e o crescimento dos animais não foi elevado, com exceção para a dieta I, na qual 
não houve diferença significativa no parâmetro ganho de peso quando comparada com a dieta padrao caseína. RODRIGUEZ et al. (1990b) afirmam que a digestibilidade não se constituiu em um instrumento definitivo para determinar a qualidade de uma proteína, já que pode-se alimentar os animais com proteína de alta digestibilidade, sem nem por isso alcançar um nível aceitável de ganho de peso; a razão é que as diferentes proteínas possuem diferente composição de aminoácidos o que determina definitivamente a qualidade de uma proteína.

Acreditamos que o teor de melaço utilizado na preparação das silagens que compunham as dietas II e III tenha influenciado o valor nutricional já que ao observarmos a fração carboidratos, podemos verificar que esta foi maior para a dieta II, que apresenta um desempenho menor. Há também a possibilidade de ter havido consumo de aminoácidos na reação de Maillard durante a secagem para amostragem do produto; pois tanto na dieta I como na dieta II foi observada diarréia nos animais durante o experimento, o que consequentemente ocasionou desidratação e perda de peso.

No geral, observa-se uma tendência, como era esperado, de se eleger a dieta I como a melhor analisada, pois apresentou melhores resultados para os parâmetros: CEA, 0,22; PER, 2,14; NPU, 51,41\% e VB, 55,23\%. No entanto, embora a caseína (dieta IV) tenha sido a dieta padrão para o ensaio biológico, a dieta I foi preparada para servir de referência às demais, uma vez que ela foi fermentada, mantendo no sistema os meios de cultura, apropriados a um bom desempenho dos microrganismos, bem como no material residual sem adição de melaço. Era esperado, portanto, que os índices medidores do desempenho dos animais, em função da proteína, fossem maiores 
nesta dieta.

A dieta III, que representa a situação prática industrial da silagem, teve bom desempenho no ensaio biológico, a saber: CEA, 0,14; PER, 1,47; D, 96,31\%; NPU, 38,68\% e VB, 40,19. 


\section{CONCLUSŌES}

1 - É viável o preparo das silagens microbianas com resíduos acidificados de sardinha (Sardinella brasiliensis) provenientes da indústria enlatadora e/ou da cmercialização, empregando-se como inóculos o Lactobacillus plantarum e o Pediococcus acidilactici.

2 - Pode-se utilizar o melaço como substrato complementar ao resíduo de pescado acidificado para o preparo da silagem microbiana.

3 - As silagens microbianas preparadas com resíduo de sardinha acidificado, adição de melaço e dos inóculos, tanto de $L$. plantarum como de $P$. acidilactici, apresentaram coloração marrom escura, aroma agradável, levemente ácido e textura de pasta.

4 - As silagens mantiveram-se estáveis, quanto ao $\mathrm{pH}$ apresentando 4,18 - 4,23, após duas semanas de fermentação.

5 - As silagens preparadas com solução inóculo $L$. plantarum e $P$. acidilactici com adição de melaço têm após $48 \mathrm{~h}$ do preparo, a seguinte composição centesimal: umidade, $55,94 \%$ e $58,83 \%$; proteína, $19,33 \%$ e $17,39 \%$; cinza, $3,77 \%$ e $3,32 \%$; carboidratos, $18,51 \%$ e $18,15 \%$ e lipídios, $2,45 \%$ e $2,31 \%$, respectivamente. 
6 - O processo fermentativo de 48 horas é suficiente para promover a hidrólise da fração protéica do material residual do pescado e produzir as silagens com solução inóculo $L$. plantarum e $P$. acidilactici que apresentam $35,18 \%$ e $39,79 \%$ de conversão do nitrogênio total a nitrogênio não protéico e digestibilidade "in vitro" de $84,2 \%$ e $84,5 \%$.

7 - É possível manter as silagens microbianas sob fermentação por um período de duas semanas com manutenção da conversão do nitrogênio, da ordem de $34,22 \%$ e $41,73 \%$ e da digestibilidade "in vitro", $83,5 \%$ e $81,0 \%$, respectivamente para as silagens preparadas com $L$. plantarum e $P$. acidilactici.

8- Sugere-se que a silagem microbiana, preparada com sardinha acidificada e adição de melaço, seja utilizada como alimento, apresentando o Coeficiente de Eficiência Alimentar de 0,14; a Razão de Eficiência Protéica de 1,47; 96,31\% de Digestibilidade "in vivo"; 38,68\% de Utilização Protéica Líquida e 40,19\% de Valor Biológico. 


\section{REFERÊNCIAS BIBLIOGRÁFICAS}

AKESON, W.R. \& STAHMAN, M.A. A pepsin pancreatic digest index of protein quality evaluation. The Journal of Nutrition, Bethesda, 83(3): 257-61, 1964.

ALMAS, K.A. Utilization of marine biomass for production of microbial growth and biochemical. In: ATLANTIC FISHERY TECHNOLOGY AND SEAFOOD BIOTECHNOLOGY WORKSHOP, 34., St. John, 1989. Papers. Lancaster, Technomic, 1989. p.361-6.

ANDRADE, M. Oetterer. Pescado fermentado. In: AQUARONE, E.; BORZANI, W.; LIMA U. de A. Alimentos e bebidas produzidos por fermentação. São Paulo, Edgard Blücher, 1983. p.176-97. (Biotecnologia, 5).

ANDRADE, M. Oetterer. Aproveitamento tecnológico do pescado. Fermentação para anchovamento. In: SIMPÓSIO NACIONAL DE FERMENTAÇÃO, 6. Fortaleza, 1984. Anais. Fortaleza, Universidade Federal do Ceará, 1984. 61p. 
ANDRADE, M. Oetterer. Fish overview in Brazil. Boletim da Sociedade Brasileira de Ciência e Tecnologia de Alimentos, Campinas, 23(3/4): 169-78, 1989.

ARECHE, T.N. \& BERENZ, V.Z. Ensilados de pescado utilizando bactérias lácticas (Lactobacillus bulgaricus, Streptococcus thermophilus). Callao, Instituto Tecnológico Pesquero del Perú, 1987. 26p.

ASSOCIATION OF OFFICIAL AGRICULTURE CHEMISTS. Official methods of analysis. 12 ed. Washington, 1975. 1018p.

ASSOCIATION OF OFFICIAL AGRICULTURE CHEMISTS. Official methods of analysis. 15 ed. Washington, 1990. p.869-70.

AUKRUST, T.T. \& BLOM, H. Tranformations of Lactobacillus strain used in meat and vegetable fermentations. Food Research International, Essex, 25: 253-61. 1992.

BACHANAN, L.; MATHEWS, S.; SVDHARMA, D.; MUKUNDAN, M.K.; MALIKA, V. Effect of fruit juices with acetic acid on the quality of pickled fish. Fishery Technology, Cochin, 29: 40-4, 1992. 
BACKHOFF, H.P. Some chemical changes in fish silage. Journal of Food Technology, Oxford, 11(4): 353-63, 1976.

BIMBO, A.P. \& CROWTHER, J.B. Fish meal and oil: current uses. Journal American Oil Chemistry Society, Chicago, 69(3): 221-7, Mar. 1992.

BORRESEN, T. Biotechnology, by products and aquaculture. In: BLIGH, E.G. Seafood science and technology, Surrey, Fishing News Books, p. 278 - 87, 1990.

BRASIL. Ministério da Indústria e Comércio. Reciclagem dos resíduos urbanos, agropecuários, industriais e minerários, síntese. Brasília, 1985. 77p.

BROWN, N. \& SUMNER, J. Fish Silage, In: RELLY A. Spoliage of tropical fish and products development. Roma, FAO, 1985. p.404-13.

CHIRASE, N.K.; KOLOPITA, M.; MALES, J.R. Fish silage for in proving the nutritional value of wheat straw. Journal of Animal Science, Albany, 61(3): 6619, 1985.

COMPOSTING fish wastes along the great lakes. BioCycle Journal of Waste Recycling, Emmaus, 32(5): 54, May 1991. 
DAS, H.K.; HATTULA, M.T.; MYLLYMÄKI, O.M.; MALKKI, Y. Effects of formulation and processing variables on dry fish feeds pellets containing fish waste. Journal of Food and Science, Champaign, 61: 181-7, 1993.

DISNEY, G.J.; TATTERSON, I.N.; OLLEN, J. Recent development in fish silage. In: CONFERENCE ON THE HANDLING PROCESSING AND MARKETING OF TROPICAL FISH, London, 1976. Proceedings. London, Tropical Products Institute, 1977. p. 321-40.

ESPE, M. RAA, J.; NJAA, L.R. Nutritional value of stored fish silage as a protein source for young rats. Journal of Science Food and Agriculture, London, 49: 259-70, 1989.

FAO. Pesca. In: . El estado mundial de la agricultura y la alimentación 1990. Rome, 1991. p.37-41. (Colección FAO: Agricultura, 23).

FAO. Fishery Statistic Yearbook - 1991, Rome, 73: 100,104,206, 1993.

FERMENTAÇÃO Controlada de silagem é testada no Brasil, Alimentos e Tecnologia, São Paulo, 27: 65, 1989. 
FREDERICK, L. Composting fishery by products. BioCycle Journal of Waste Recycling, Emmaus, 33(1): 85, Jan. 1992a.

FREDERICK, L. Turning fishery wastes into saleable compost. BioCycle Journal of Waste Recycling, Emmaus, 32(9): 85, Sept. $1992 \mathrm{~b}$.

FREITAS, J.V.T. \& GURGEL, J.J.S. Sobre o aproveitamento de resíduos do pescado dos açudes do nordeste, na elaboração de subprodutos. Boletim Técnico do DNOCS, Fortaleza, 32(2): 139-47, jul/dez. 1976.

GILBERT, A. \& RAA, J. Properties of a propionic acid/formic acid preserved silage of food viscera. Joumal of Science Food and Agriculture, London, 28: 647-53, 1977.

GOMES, F.P. Curso de estatística experimental. 10 ed. São Paulo, Nobel, 1987. 430p.

GREENSHIELDS, R.N. The biotech concept and food processing wastes. Outlook on Agriculture, Bracknell, 21(2): 99-104, 1992. 
GURGEL, J.J.S. \& FREITAS, J.V.F. Aproveitamento final do pescado dos açudes do nordeste brasileiro após beneficiado. Boletim Técnico DNOCS, Fortaleza, 31(1): 38-44, jan./jun. 1973.

HAARD, N.F.; KARIEL, N.; HERZBERG, G; FELTHAM, L.A.W.; WINTER, K. Stabilization of protein and oil in fish silage for use as a ruminante feed suplement. Journal of Science Food and Agriculture, London, 36: 229-41, 1985.

HALL, G.M. Fish processing technology, London, Blackie Academic \& Profissional, 1992. 309p.

HARTMAN, L. \& LAGO, R.C.A. Rapid preparation of fatty acid methyl ester from lipids. London, Lab. Pract., 1973.

HASSAN, T.E.; HEATH, J.L. Biological fermentation of fish wastes for potential use in animal and poultry feeds. Agriculture Wastes, Barking, 15(1): 1-15, 1986.

HASSAN, T.E.; HEATH, J.L. Chemical and nutritive characteristics of fish silage produced by biological fermentation. Biological-Wastes Working, Barking, 20(3): 187-201, 1987. 
HERIBAN, V.; STURDIK, L.Z.; MATUS, P. Process and metabolic characteristics of Bacillus coagulans as a lactic acid producer. Letters in Applied Microbiology, s.1., 16: 243-6, 1993.

HERON, S.J.E.; WILKINSON, J.F.; DUFFUS, C.M. Enterobacteria associated whith grass and silages. Journal of Applied Bacteriology, Oxford, 75, p. 13-7, 1993.

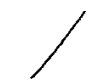

HOOD, L.F. \& ZALL, R.R. Recovery, utilization and treatment of seafood processing wastes. Advances Fishery Science and Technology, Surrey, p.355-61, 1980.

HORISBERGER, M. Lessons from the past for better future utilization of fish resources. In: NESTLÉ RESEARCH NEWS. 1978/79. Lausanne, Nestlé Products Technical Assistance, 1979. p.41-9.

HOSSAIN, M.A.; FURUICHI, M.; YONE, Y. POV. TBA and VBN values and proximate, aminoacid and fatty acid compositions of scrap meals fermented with fungi. Nippon Suisan, Gakkaishi, 53(9): 1629-32, 1987.

INSTITUTE of Food Technology. Seafood products technology group, 9(2): 11-3, March. 1992. 
INTERNATIONAL COMISSION ON MICROBIOLOGICAL ESPECIFICATIONS FOR FOODS (ICMSF). Ecologia microbiana de los alimentos. Zaragoza, Acribia, 1980 p.2.

JAMES, M.A; IYER, K.M.; NAIR, M.R. Comparative study of fish silage prepared by microbial fermentation and formic acid silage. In: CONFERENCE ON THE HANDLING PROCESSING AND MARKETING OF TROPICAL FISH, London, 1977. Proceedings. London, Tropical Products Institute, p.273-5, 1977.

JOHNSON, R.J.; BROWN, N.; EASON, P; SUMNER, J. The nutritional quality of two types of fish silage for broiler chickens. Journal of the Science of Food and Agriculture, London, 36(11): 1051-6, 1985.

JONES, H.R. Pollution control in meat, poultry and seafood processing. New Jersey, Noyes, 1974. p.215-46.

KARMAS, E. \& LAUBER, E. Novel products from underutilized fish using combined processing technology. Journal of Food Science, Champaign, 52(1): 7-9, Jan./Feb. 1987. 
KHETARPAUL, N. \& CHAUHAN, B.M. Fermentation of pearl millet flour with yeast and lactobacilli: in vitro digestibilidade and utilization of fermented flour for weaning mixtures. Plant Food for Human Nutrition, London, 40: 167-73, 1990.

KOMPIANG, I.P. Fish silage, its prospect and future in Indonesia. Indonesian Agricultural Research \& Development Journal, Jackarta, 3(1): 9-12, 1981.

KOMPIANG, I.P. Fish silage and tepsil production technology. Indonesian Agriculture Research and Development Journal, Bogor, 12(4): 55-9, 1990.

KOMPIANG, I.P.; YUS ADHI; CRESWELL, D.C. Microbial fish silage: chemical composition, fermentations característics and nutritional value. In: IPFC Workshop Fish Silage, Roma, 1980. Proceedings. Roma, FAO, 1980. p.44-7. 1980. (Fish Report n⿳2 230).

LAJOLO, F.M. Avaliação biológica de produtos obtidos por bioconversão. Boletim da Sociedade Brasileira de Ciência e Tecnologia de Alimentos, Campinas, 18(2): 153-9, abr./jun. 1984.

LAUBIER, L. Aquaculture: biological aspects and economic considerations. In: NESTLÉ RESEARCH NEWS. 1978/79. Lausanne, Nestlé Products Technical Assitance, 1979. 
LEVIN, R.E. \& WITKOWSKI, R. Characteristics and identity of obligately aerobic spoilage yeast from fish silage. Journal Applied Bacteriology, Reading, 7(4): 354-9, 1991.

LINDGREN, S. \& PLEJE, M. Silage fermentation of fish or fish waste products with lactic acid bacteria. Journal Science Food Agricultural, London, 34: 1057-67, 1983.

LISTON, J. Avanços na tecnologia de pescados para melhor aproveitamento de espécies industrializadas de baixo valor comercial. Boletim do Instituto de Tecnologia de Alimentos, Campinas, 53: 1-20, 1977.

LUNA, G.; REY, J.L.; CASTRO, L.M.; CORONA, N.; FERREIROS, E; LUZARDO, M. Elaboración y análisis de harinas codeshidratadas de vegetales y especies de pescado subutilizadas. I: codeshidratados de cereal - pescado. Archivos Latinoamericanos de Nutrición, Guatemala, 40(3): 395-407, 1990.

MAHARAJ, V. \& RECKSIEK, C. The by-catch from the artesanal shrimps trawl fishery, Gulf of Paria, Trinidad. Marine Fisheries Review, Washington, 53(2): 9-15, Mar./Apr. 1991. 
MANIKANDAVELU, D.; NEETHISELVAN， JAGATHEESAN， G.; SUNDARSANAM, K. Use of fermented ensilage based diet in enhancing the growth of common carp (Cyprinus carpio var. communis). Fishery Technology, Cochin, 29: 111-3, 1992.

McNAUGHTON, J.L.; MAY, J.D; REECE, F.N.; DEATON, W. Broiler chick utilization of hydrolysed fish protein, Poultry Science, Ithaca, 57:1151, 1985.

MEZINCESCU, M.D. \& SZABO, F. Method for the determination of the non-protein of tissue. Joumal Biological Chemistry, Baltimore, 115: 131-8, 1936.

MILLER, D.S. \& BENDER, A.C. The determination of net utilization of protein by shortened method. British Joumal of Nutrition, Cambridge, 9:382-3, 1955.

MORAIS, C. \& MARTINS, J. Considerações sobre o aproveitamento de sobras da industrialização de pescado na elaboração de produtos alimentícios. Boletim do Instituto de Tecnologia de Alimentos, Campinas, 18(3): 253-81, 1981.

NUNES, M.L. Resíduos de pescado: aproveitamento sob a forma de silagem. In: CONGRESSO BRASILEIRO DE CIÊNCIA E TECNOLOGIA DE ALIMENTOS, 13., São Paulo, 1992. Anais. São Paulo, Sociedade Brasileira de Ciência e Tecnologia de Alimentos, 1992. p.137. 
OETTERER, M. Matérias primas alimentares; pescado. São Caetano do Sul, Centro de Pesquisas, 1991. 30p.

QETTERER, M; VALÉRIO. A.C.R.; SZENTTAMASY, E.R.; BARBOSA, S.M.B.; MORENO, I.A.M. Aproveitamento da biomassa residual da industrialização do pescado. In: CONGRESSO BRASILEIRO DE CIÊNCIA E TECNOLOGIA DE AlimentOS, 13., São Paulo, 1992. Anais. São Paulo, SBCTA, 1992. p.140.

OETTERER, M. Produção de silagem a partir da biomassa residual de pescado. Alimentação e Nutrição, São Paulo, 5: 119-34, 1993/94.

OSBORNE, T.B.; MENDEL, L.B.; FERRY, E.L. A method of expressing numerically the growth-promoting value of proteins. Journal of Biological Chemistry, Baltimore, 37: 223-9, 1919.

OTTATI, M.; GUTIERREZ, M.; BELLO, R.A. Estudio sobre la elaboración de ensilado microbiano a partir de pescado proveniente de especies subutilizadas. Archivos Latinoamericanos de Nutrición, Guatemala, 40(3): 411-25, jul., 1990.

PAN, B.S. Recovery of shrimp waste for flavourant. In: Atlantic Fishery Technology Conference Seafood Biotechnology Workshop, 34., St. John's, 1989. Papers. Lancaster, Technomic, 1989. p.437-52. 
RAA, M.E.J. \& NJAA, L.R. Nutritional value of stored fish silage as a protein source for young rats. Journal of Science Food and Agriculture, London, 49: 259-70, 1989.

REBECA, B.D.; PEÑA-VERA, M.T.; DIAS CASTAÑERA, M. Production of fish protein hidrolysates with bacterial proteases; yield and nutritional value. Journal of Food Science, Champaign, 56(2): 2309-14, 1991.

REGENSTEIN, J.M. Fish waste: resource recovery workshop. IFT, Blacksburg, 8(2):5-6, Mar. 1990.

REYES, G.; MARTINEZ, R.; RODRIGUEZ, L.M.; BELLO, R.A.; PASCUAL, M.C. Efecto de la adición de desechos de frutas tropicales sobre la velocidade de producción de ensilado microbiano de pescado. Alimentaria, Madrid, 99-108, ene/feb, 1991.

RODRIGUEZ, T.; MONTILLA, J.J.; BELLO. R.A. Ensilado de pescado a partir de la fauna de acompañamiento del camarón. I - Elaboración y evaluación biológica. Archivos Latinoamericanos de Nutrición, Guatemala, 40(4): 427-37, Sep., 1990a. 
RODRIGUEZ, T.; MONTILLA, J.J.; BELLO, R.A. Ensilado de pescado a partir de la fauna de acompañamiento del camarón. II - Prueba de comportamiento em pollos de engorde. Archivos Latinoamericanos de Nutrición, Guatemala, 40(4):548-59, Sep. $1990 \mathrm{~b}$.

SALES, R.O.; OLIVEIRA, A.C.; GUIMARĀES, J.G.L. Elaboração de autolisado ácido (silagem) de tilápia (Sarotherodon niloticus) e acompanhamento do processo de autolólise. In: CONGRESSO BRASILEIRO DE CIÊNCIA E TECNOLOGIA DE ALIMENTOS, 13., São Paulo, 1992. Anais. São Paulo, SBCTA, 1992. p.130.

SANKAR, T.V. \& SOLANKI, K.K. Changes in nitrogen fractions in the fillets of elasmobranchs during salting. Fishery Technology, Cochin, 29(1): 47-7, Jul. 1992.

SEAL, K.J. Animal wastes as source of biomass production. Outlook on Agriculture, Bracknell, 21(2): 91-7, 1992.

SHOEMAKER, S. The use of enzymes for waste manegement in food industry. In: HARLANDER, S.K. \& LABUZA, T.P. Biotechnology in food processing, New Jersey, Noyes Publ., 1986. p.259-69. 
SMALL-SCALE fish composting trials. BioCycle Journal of Waste Recicling, Emmaus, 33(2):62, Feb. 1992.

SPENCER, R. Food waste composting in Canada. BioCycle Journal of Waste Recicling, Emmaus, 31(6): 30-2, Jun. 1990.

STANTON, W.R. \& YEOH, Q.L. Low salt fermentation for conserving trash fish waste under SE Asian conditions. In: CONFERENCE ON THE HANDLING, PROCESSING AND MARKETING OF TROPICAL FISH, London, 1977. Procedings, London, Tropical Products Institute, p. 277-282, 1977.

STONE, F.E. \& HARDY, R.W. Nutritional value acid stabilized silage and liquefied fish protein. Journal of Science and Agriculture, London, 37: 797-803, 1986.

STROM, T. \& EGGUM, B.O. Nutritional value of fish viscera silage. Journal of Science Food and Agriculture, London, 32:115-20, 1981.

STROM, T.; GILBERT, A.; STORMO, B.; RAA, J. Fish silage: why not use propionic and formic acid? Advances Fish Science Technology, Surrey, 352-5, 1979. 
SURIMI; a alternativa contra o desperdício de pescado. Revista Nacional da Carne, São Paulo, 18(207): 78, 1994.

TATTERSON, J.N. \& WINDSOR, M.L. Fish silage. Journal of Science Food and Agriculture, London, 25:369-79, 1974.

TATTERSON, J.N. \& WINDSOR, M.L. Fish silage. Aberdeen, Ministry of Agriculture, Fisheries and Food/Torry Research Station, s.d. 6p. (Torry Advisory Note, 64).

TENUTA FILHO, A. Caracterização nutricional e funcional da proteína recuperada de cefalotótax de camarão rosa e estudo do aproveitamento do produto residual. São Paulo, 1983. 79p. (Doutoramento - Faculdade de Farmácia e Bioquímica / USP).

TEUTSCHER, F. Pescado alimentación, nutrición humana. Alimentación y Nutrición, Roma 12:2 p. 2-10, 1986.

UNITED NATIONS INDUSTRIAL DEVELOPMENT ORGANIZATION. - UNIDO Environmental management in fishery-based industries. 1991. 88p. (Working Papers in Industrial Planning, 5). 
VENUGOPAL, V.; ALUR, M.D.; NERKAR, D.P. Solubilization fish proteins using imobilized microbial cells. Biotechnology and Bioengineering, New York, 33: 1098-103, 1989.

VIEIRA, G.H.F.; SAKER-SAMPAIO, S.; GONÇALVES, R.C.F.; REIS, S.B. Preparação de peptona a partir de subproduto do pescado. In: CONGRESSO BRASILEIRO DE CIÊNCIA E TECNOLOGIA DE ALIMENTOS, 13. São Paulo, 1992. Programa e resumos. São Paulo, SBCTA, 1992. p.227.

WHEATON, F. W. \& LAWSON, T.B. Processing aquatic food products. New York, John Willey \& Sons, 440p. , 1985.

WINDSOR, M.L. Production of liquid fish silage for animal feed. In: KREUZER, R. Fishery products. London, FAO/Fishing News, 1979, p.140-4.

WYK, H.J. Van \& HEYDENRYCH, C.M.S. The production of naturally fermented fish silage using various lactobacilli and different carbohydrates sources. Journal of the Science of Food and Agriculture, London, 36(11): 1093-1103, 1985.

YONE, Y.; HOSSAIN, M.A.; FURUICHI, M.; KATO, F. Effect of fermented and fermented-resteamed scrap meals on growth and feed efficiency of red sea bream. Bulletin Japanese Society Fisheries, Tokio, 52(3): 549-52, 1986. 